\title{
Comparative transcriptomics and cellular analysis reveal the tolerance mechanisms of Candida tropicalis towards phenol as the representative phenolic inhibitors from lignocellulosic hydrolysis
}

\section{Hanyu Wang}

Sichuan Agricultural University

Qian Li

Sichuan Agricultural University

Yuanyuan Peng

Sichuan Agricultural University

Zhengyue Zhang

Sichuan Agricultural University

Xiaolin Kuang

Sichuan Agricultural University

Xiangdong $\mathrm{Hu}$

Sichuan Agricultural University

Ellen Ayepa

Sichuan Agricultural University

Xuebing Han

Sichuan Agricultural University

Getachew Tafere Abrha

Sichuan Agricultural University

Quanju Xiang

Sichuan Agricultural University

Xiumei Yu

Sichuan Agricultural University

Ke Zhao

Sichuan Agricultural University

Likou Zou

Sichuan Agricultural University

Yunfu Gu

Sichuan Agricultural University

Xi Li

Sichuan Agricultural University 


\section{Xiaoying Li}

Chongqing University of Arts and Sciences

\section{Qiang Chen}

Sichuan Agricultural University

\section{Xiaoping Zhang}

Sichuan Agricultural University

\section{Beidong Liu}

Goteborgs Universitet

Menggen Ma ( $\sim$ mgen@sicau.edu.cn )

Sichuan Agricultural University

\section{Research}

Keywords: Candida tropicalis, Lignocellulose, Morphological observation, Phenol, Reactive oxygen species (ROS), Transcriptome

Posted Date: December 9th, 2019

DOI: https://doi.org/10.21203/rs.2.18474/v1

License: (c) (i) This work is licensed under a Creative Commons Attribution 4.0 International License. Read Full License 


\section{Abstract}

Background: Phenolics derived from lignocellulose severely influence cell growth and fermentation ability in yeast. Due to its high tolerance for various stresses, Candida tropicalis has recently emerged as a promising strain for the degradation of industrial sewage. Great efforts have been made on studying the degradation machineries of phenol by $\mathrm{C}$. tropicalis, but the global mechanisms underlying its tolerance of high concentrations of phenolics remain ambiguous. Since the substructure and toxicity of phenol are similar to those of other phenolic compounds derived from lignin hydrolysis, we treated C. tropicalis cells with phenol as a representative substance for the phenolic compounds. Results: We found that after treatment with $0.5 \mathrm{~g} / \mathrm{l}, 1.0 \mathrm{~g} / \mathrm{l}$, and $2.0 \mathrm{~g} / \mathrm{I}$ phenol, the growth of $\mathrm{C}$. tropicalis SHC-03 was inhibited, but recovered completely after a lag phase. Although we found that $\mathrm{C}$. tropicalis could degrade phenol when phenol was used as the sole carbon source, it could not degrade phenol in YPD medium, implying that increased tolerance for phenol contributed to the recovery of cell growth. Morphological observation demonstrated that phenol could induce reactive oxygen species (ROS) accumulation, mitochondrial membrane damage, and damage to the endoplasmic reticulum (ER), but did not affect the structural stability of chromatin. On the basis of transcriptome data and cell wall susceptibility analysis, a number of genes related to DNA repair, DNA replication, heat shock protein (HSP)-mediated proteasomal degradation, autophagy, accumulation of fatty acids, cell wall remodeling, and MDR/MXR transporters were found. These genes may play key roles in the increased tolerance of $\mathrm{C}$. tropicalis to phenol stress. Conclusion: $\mathrm{C}$. tropicalis appears to prevent phenol-induced cell damage through maintenance of highfidelity DNA replication, intracellular protein homeostasis, organelle integrity, and keep the intracellular phenol concentration at a low level through cell-wall remodeling and removal of excess phenol via MDR/MXR transporters. The knowledge obtained from this research provided us with a global understanding of phenolic tolerance mechanisms in C. tropicalis and will promote the genetic modification of yeast strains to develop biological products using lignocellulosic hydrolysates as a carbon resource.

\section{Background}

Lignocellulose biomass, as the most abundant and sustainable resource in the world, is extensively applied in fermentative production of biofuels, biochemicals, and food additives by microorganisms [13]. As lignocellulose is polymerized from cellulose, hemicellulose, and lignin, it cannot be directly utilized by microorganisms $[4,5]$. Thus, a pretreatment method must be integrated into the bio-production process in order to successfully convert lignocellulose to sugars prior to fermentation [6]. Among the numerous pretreatment methods, dilute sulfuric acid hydrolysis is the most simple, fast, and economic one. However, this method inevitably generates inhibitors, which could inhibit microbial cell growth and subsequent fermentation [7]. Given the main chemical groups, these inhibitors can be roughly divided into aldehydes, phenolics, and organic acids [8]. The phenolics derived from lignin have been identified as one of the most important categories of inhibitors, due to their complex composition (including phenolic monomers, phenolic aldehydes, and phenolic acids) in terms of chemical structure, and complicated toxic 
effects on cells [8-13]. Previous studies confirmed that the removal of phenolics could substantially improve the fermentability of hydrolysates, and ethanol productivity $[12,14]$. Therefore, to neutralize and/or remove phenolics from hydrolysates, a series of physical, chemical, and/or physiochemical methods have been explored and applied [15-17]. However, due to economic constraints, these methods are not suitable for application in the industrial production of biological products.

Recently, several studies have shown that application of inhibitor-tolerant strains could reduce the industrial production cost of these biological products $[8,18]$. In recent years, a range of tolerance mechanisms have been discovered through next-generation sequencing. For example, some inhibitortolerant strains of microorganisms detoxify phenolic aldehydes and acids to phenolic metabolites with less toxicity through reduction and/or decarboxylation reactions, which can shorten the lag phase and maintain the viability of the cells [19-21]. However, the aromatic groups and phenolic hydroxyl groups in these phenolic metabolites are still toxic to the cells, and could inhibit cell growth in the microorganisms [22]. Although several studies have found that chromatin remodeling, efflux of toxic compounds, and aggregation of lipopolysaccharides on the outer cell membrane could increase the resistance of fermenting strains to phenolics [22-24], these studies were unable to comprehensively characterize the mechanisms of tolerance to phenolics. Phenolic monomer (phenol) is one of the inhibitors derived from lignocellulosic biomass. Since it includes both the aromatic group and phenolic hydroxyl group, phenol can effectively represent the phenolic inhibitors from lignocellulosic hydrolysis and can be used to explore the mechanisms of microorganisms' tolerance to these compounds. A previous study focused on the fermenting microorganism Rhodococcus opacus PD630 found that phenol tolerance mainly involved the import and degradation of extracellular phenol [24]. Since R. opacus PD630 is a bacterial strain and phenol was used as the sole carbon source, not as an inhibitor, this study could not thoroughly demonstrate the tolerance mechanisms of yeast strains to phenol.

Candida tropicalis can not only utilize a range of carbon sources, including disaccharides and other sugars, phenols, alkanes, alkane derivatives, and fatty acids, but can also produce a range of biological products, including xylitol and long-chain dicarboxylic acids [25-28]. Additionally, C. tropicalis has the ability to tolerate high concentrations of salts, heat, phenol, furfural, and acetic acid [29-31]. The genome of C. tropicalis has been completely sequenced [32], enabling transcriptome analysis of C. tropicalis in different conditions. Additionally, based on phylogenetic analysis, the genome of $\mathrm{C}$. tropicalis is found to be remote from that of Saccharomyces cerevisiae which is one of the most promising microorganisms for fermentative production of biofuels, biochemicals, and food additives from lignocellulose [32]. These results suggest that several molecular mechanisms utilized by $\mathrm{C}$. tropicalis are distinct from those utilized by S. cerevisiae. Improving the tolerance mechanisms of the fermenting stains to phenolic inhibitors derived from lignocellulose is important, as is analyzing and studying the tolerance mechanisms of $\mathrm{C}$. tropicalis to phenol. To date, most studies on the tolerance mechanisms of $\mathrm{C}$. tropicalis to phenol have focused on the degradation of phenol by biodegradation, but not the molecular and cellular mechanisms underlying its resistance to high concentrations of phenol [33-36]. In this study, pre-cultured cells of C. tropicalis strain SHC-03 (isolated from distillers' grains from a liquor brewery in Shehong County, Suining, Sichuan, China) were treated with phenol in order to explore the possible 
molecular and cellular mechanisms underlying phenol tolerance via fluorescence microscopy and comparative transcriptomics.

\section{Results}

\section{Growth and phenol consumption in phenol-supplemented medium}

To investigate the tolerance of $C$. tropicalis SHC-03 to phenol, we transferred the pre-cultured cells into yeast extract peptone dextrose (YPD) medium containing $0.0 \mathrm{~g} / \mathrm{l}, 0.5 \mathrm{~g} / \mathrm{l}, 1.0 \mathrm{~g} / \mathrm{l}, 2.0 \mathrm{~g} / \mathrm{l}$, and $3.0 \mathrm{~g} / \mathrm{l}$ phenol, and observed the pattern of cell growth (change in cell density). The initial concentration of cells in the culture was adjusted to approximately $1.0^{\prime}$ absorbance value (optical density at $600 \mathrm{~nm}$ wavelength, $O D_{600}$ ). Compared with the non-phenol-treated culture, the cell growth of phenol-treated $C$. tropicalis SHC-03 was slightly inhibited when the media contained $0.5 \mathrm{~g} / \mathrm{l}$ and $1.0 \mathrm{~g} / \mathrm{l}$ phenol (Fig. $1 \mathrm{~A})$. However, in the presence of $2.0 \mathrm{~g} / \mathrm{l}$ and $3.0 \mathrm{~g} / \mathrm{l}$ phenol, cell growth was hindered by approximately $40 \%$ and $100 \%$, respectively (Fig. 1A). As illustrated in Fig. 1A, the growth rate of cells treated with $2.0 \mathrm{~g} / \mathrm{l}$ phenol remained at a low level from $3 \mathrm{~h}$ to $24 \mathrm{~h}$, implying that the phenol caused cell damage and influenced cell growth. However, after treatment for $24 \mathrm{~h}$ in the presence of $2.0 \mathrm{~g} / \mathrm{l}$ phenol, the cells returned to normal levels of growth.

We speculated that phenol might be degraded to less toxic products via the $\beta$-ketoadipate pathway in $C$. tropicalis SHC-03 [33]. We therefore used the 4-aminoantipyrine spectrophotometric method to test for biodegradation of phenol in the different treatments (Fig. 1B). The results revealed no significant change in the concentration of phenol in any of the treatments at 0-72 h (Fig. 1B), which indicated that the phenol degradation mechanism of $C$. tropicalis SHC-03 was not activated in these conditions. To summarize, a range of resistance and/or detoxification mechanisms for protecting cells from the toxic damage of phenol were activated during the lag phase. Therefore, we employed RNA-seq technology and cytological techniques to reveal the potential tolerance mechanisms of $C$. tropicalis to phenol.

\section{RNA-Seq, transcriptomic analysis, and qRT-PCR assays}

After incubation with or without phenol for $3 \mathrm{~h}$, the cells were harvested for RNA-seq (NCBI Accession Number: PRJNA591802). Based on quality-control test results, it was found that the quality score $\left(\mathrm{Q}_{30}\right)$, clean data, and sequencing depth of each sample was, respectively, more than $94 \%, 4 \mathrm{~Gb}$, and $675 \times$ (Additional File 1), which indicated a high level of accuracy for the RNA-seq results. To mitigate errors induced by biological variability between the samples, three biological replicates were used for the RNAseq. The classification of the groups receiving different concentrations of phenol were as follows: $0.0 \mathrm{~g} / \mathrm{l}$ : T01, T02, T03; 0.5 g/l: T04, T05, T06; 1.0 g/l: T07, T08, T09; 2.0 g/l: T10, T11, T12. As illustrated in Fig. 2A, the correlations between T01, T06, T09 and their corresponding biological replicates were relatively low. To guarantee reliability and accuracy of the results from the differential expression analysis, T01, T06, and T09 were eliminated (Fig. 2B). 
The expression pattern of the $0.5 \mathrm{~g} / \mathrm{l}$ phenol group was highly consistent with that of the control group; only 39 genes and 40 genes showed up- and down-regulated expression, respectively, with twofold changes in the $0.5 \mathrm{~g} / \mathrm{l}$ phenol group compared with the control (Fig. 2D and 2E). In contrast, for the 1.0 and $2.0 \mathrm{~g} / \mathrm{l}$ phenol groups, 353 and 1985 genes showed altered expression levels, respectively (Fig. 2C). Among these genes, 215 and 1050 genes were identified as up-regulated genes in the 1.0 and $2.0 \mathrm{~g} / \mathrm{l}$ phenol groups, respectively (Fig. 2D), and 138 and 935 genes, respectively, were repressed by phenol (Fig. $2 \mathrm{E}$ ). To sum up, the number of differentially expressed genes rose along with increasing phenol concentration.

In this study, 21 differentially expressed genes in response to $1.0 \mathrm{~g} / \mathrm{l}$ phenol were selected to validate the accuracy of the results from RNA-seq through a qRT-PCR assay. The criterion for gene selection was a combination of high-low gene expression level (FPKM) and absolute value of $\log _{2}$ (fold change). Through comparison and analysis, we discovered that the expression levels of 18 of 21 genes (approximately 85\%) were consistent in the trend of up- and down-regulation (Fig. 2F). Of the other three genes, inconsistent with the data from RNA-seq, two displayed lower abosolute values of $\log _{2}$ (fold change) (Fig. 2F). In summary, the results from RNA-Seq showed high accuracy, which contributed to the exploration of the phenol tolerance mechanism utilized by $C$. tropicalis.

\section{Accumulation and scavenging of reactive oxygen species (ROS) in cells}

Previous studies have found that phenol can pass through the cellular membrane and lead to increased membrane permeability and decreased membrane lipid-to-protein ratios, indicating the potential for phenol to cause dysfunction of organelles containing membranes, such as mitochondria, the endoplasmic reticulum, and the vacuole [9-11]. To detect damage to the mitochondrial membrane, Mito Tracker $^{\mathrm{TM}}$ Green FM was used to stain the untreated and treated cells. Under phenol stress, the mitochondrial membrane displayed four different types of morphologies. In order of increasing damage, these were: tubular, fragmented, aggregated shapes, and necrotic (Fig. 3A). At $3 \mathrm{~h}$, cells grown in media containing $0.0 \mathrm{~g} / \mathrm{l}$ and $0.5 \mathrm{~g} / \mathrm{l}$ phenol displayed tubular (95\% and 50\%, respectively) and fragmented (5\% and $50 \%$, respectively) mitochondria, while cells grown in media containing $2.0 \mathrm{~g} / \mathrm{l}$ and $3.0 \mathrm{~g} / \mathrm{l}$ phenol displayed aggregated ( $84 \%$ and $70 \%$, respectively) and necrotic mitochondria ( $16 \%$ and $30 \%$, respectively) (Fig. 3C). In contrast, at $9 \mathrm{~h}$, only $3 \%$ of the non-phenol-treated cells appeared to be necrotic. At the same time point, among cells grown in $0.5 \mathrm{~g} / \mathrm{l}$ phenol, the percentage of cells with aggregated and necrotic mitochondria remained at a low level ( $1 \%$ and $2 \%$, respectively) (Fig. $3 \mathrm{C}$ ). At $18 \mathrm{~h}$, cells with tubular mitochondria were no longer seen in cells grown in media with or without phenol. In addition, compared with the results at $3 \mathrm{~h}$ and $9 \mathrm{~h}$, the distribution of cells containing aggregated mitochondria increased tremendously, with $95 \%$ of the yeast cells cultured in $1.0 \mathrm{~g} / \mathrm{l}$ phenol showing aggregated mitochondria at $18 \mathrm{~h}$. Furthermore, in cells cultured in $2.0 \mathrm{~g} / \mathrm{l}$ and $3.0 \mathrm{~g} / \mathrm{l}$ phenol, the proportion of necrotic cells increased to $33 \%$ and $58 \%$ at $18 \mathrm{~h}$, respectively (Fig. $3 \mathrm{C}$ ). In summary, the ratio of mitochondrial deformation increased with the elevation of phenol concentration and treatment duration. 
As most of the exogenous ROS were produced by damaged mitochondria [35], we hypothesized that cells treated with phenol should display excessive ROS. Therefore, 2' 7'-dichlorofluorescein diacetates (DCFHDA) was employed to stain the treated and untreated cells in order to detect intracellular ROS. The percentage of cells staining positive for ROS was considered to be representative of severity of oxidative stress (Fig. 3B). Cultures in media containing $2.5 \mathrm{mM}, 5.0 \mathrm{mM}$, and $7.5 \mathrm{mM}$ hydrogen peroxide served as the positive controls for ROS (Fig. 3D). In the medium without phenol, at $3 \mathrm{~h}$ and $9 \mathrm{~h}$ after treatment at $30^{\circ} \mathrm{C}, 5.6 \%$ and $6.5 \%$ of the cells exhibited a positive ROS signal, respectively (Fig. 3D). At $3 \mathrm{~h}, 9.1 \%$, $10.2 \%, 30.3 \%$, and $42.1 \%$ of cells stained positive for ROS when $0.5 \mathrm{~g} / \mathrm{l}, 1.0 \mathrm{~g} / \mathrm{l}, 2.0 \mathrm{~g} / \mathrm{l}$, and $3.0 \mathrm{~g} / \mathrm{l} \mathrm{phenol}$ were present, respectively (Fig. 3D), showing that the proportion of cells with ROS increased with increasing phenol concentration. At $9 \mathrm{~h}$, the percent of these same cells staining positive for accumulated ROS had become $5.7 \%, 12.8 \%, 11.6 \%$, and $100.0 \%$, respectively (Fig. 3D). In addition, in the presence of $2.5 \mathrm{mM}, 5.0 \mathrm{mM}$, and $7.5 \mathrm{mM}$ hydrogen peroxide, $13.2 \%, 30.0 \%$, and $53.1 \%$ of cells which had shown a positive ROS signal at $3 \mathrm{~h}$ decreased to $4.2 \%, 6.8 \%$, and $5.6 \%$ at $9 \mathrm{~h}$, respectively (Fig. 3D). The above results implied that the accumulation of ROS reached its peak at $3 \mathrm{~h}$ after treatment, and that, while the accumulation of excessive ROS at this time might cause damage to DNA, proteins, and lipids [37-39], the intracellular ROS were eliminated by several molecular mechanisms between $3 \mathrm{~h}$ and $9 \mathrm{~h}$ after treatment.

Efficient enzymatic and non-enzymatic antioxidant defense systems were found to be responsible for the scavenging of excessive ROS and protection of cells from oxidative damage [36]. Superoxide dismutases (SODs), glutathione peroxidases (GPX), catalase (CTT), glutathione reductase (GLR) and other scavenging enzymes functioned as enzymatic scavengers in enzyme-based antioxidant defense systems (Additional File 2). Thus, we investigated the transcription levels of these genes in the treated samples (Additional File 2). Based on the transcriptome data, we found that the expression levels of most of these genes were not significantly up-regulated against $0.5,1.0$, and $2.0 \mathrm{~g} / \mathrm{l}$ phenol (Additional File 2). Among these genes, CTRG_04448, CTRG_04203, CTRG_01769, CTRG_00610, and CTRG_05111 exhibited 4.3-, 2.3-, 2.1-, 4.0-, and 3.2-fold downregulation, and CTRG_03986, CTRG_00152, CTRG_06042, and CTRG_02189 displayed 3.0-, 2.5-, 2.1-, and 2.6-fold upregulation when exposed to $2.0 \mathrm{~g} / \mathrm{l}$ phenol (Additional File 2). In addition, one of these genes, CTRG_00142, displayed 2.1-fold upregulation when exposed to $1.0 \mathrm{~g} / \mathrm{l}$ phenol. Given the transcriptome data, we had hypothesized that the enzymatic antioxidant defense systems would not be significantly activated for scavenging excessive ROS at $3 \mathrm{~h}$. In contrast, the above results from the determination of ROS showed that the excessive ROS in the phenoltreated cells were scavenged between $3 \mathrm{~h}$ and $9 \mathrm{~h}$ (Fig. 3D).

The major ROS-scavenging pathways, the reduction of superoxide anion radicals $\left(\mathrm{O}_{2}^{-}\right)$and hydrogen peroxide $\left(\mathrm{H}_{2} \mathrm{O}_{2}\right)$, is catalyzed by SOD, GPX, and CTT (Fig. 4A) [36]. Therefore, we carried out enzyme activity assays for SOD, CTT, and GPX in the phenol-treated and non-phenol-treated cells (Fig. 4B, C). The results from the enzyme activity assays for SOD showed that, at $3 \mathrm{~h}$, the enzyme activity of intracellular SOD increased dramatically along with increasing phenol concentration (Fig. 4B). At 6 h, the SOD activity of cells treated with $2.0 \mathrm{~g} / \mathrm{l}$ phenol was significantly higher than that of cells treated with $0.0,0.5$, and 1.0 $\mathrm{g} / \mathrm{l}$ phenol, but the SOD activity in cells treated with $3.0 \mathrm{~g} / \mathrm{l}$ phenol was considerably lower (Fig. 4B). The 
SOD activities of all the treatments were lower at $6 \mathrm{~h}$ than those of the corresponding treatments at $3 \mathrm{~h}$. However, few samples exhibited any SOD activity at $9 \mathrm{~h}$ (Fig. 4B). Since GPX and CTT are the key enzymes for the reduction of $\mathrm{H}_{2} \mathrm{O}_{2}$ (Fig. 4A), the activity of both of these enzymes was assayed. We found no significant differences in GPX activity in any of the treatments at $3 \mathrm{~h}$. However, cells treated with $1.0 \mathrm{~g} / \mathrm{l}$ phenol exhibited an increase in GPX activity at $9 \mathrm{~h}$, and cells treated with $2.0 \mathrm{~g} / \mathrm{l}$ phenol exhibited an increase in GPX activity at $6 \mathrm{~h}$ and $9 \mathrm{~h}$. At both $6 \mathrm{~h}$ and $9 \mathrm{~h}$, cells treated with $3.0 \mathrm{~g} / \mathrm{l}$ phenol had lost their GPX activity almost completely (Fig. 4C). These results indicated that GPX activity was significantly upregulated in cells treated with $1.0 \mathrm{~g} / \mathrm{l}$ and $2.0 \mathrm{~g} / \mathrm{l}$ phenol after $6 \mathrm{~h}$ and $9 \mathrm{~h}$, but that the high concentration of phenol ( $3.0 \mathrm{~g} / \mathrm{l}$ phenol) induced the loss of cellular GPX activity at $6 \mathrm{~h}$. With regard to CTT, the enzyme activity assays demonstrated no CTT activity in either phenol-treated or non-phenoltreated cells at the different processing times (data not shown). In addition, it has been found that high GLR activity and high GSH content can support high catalytic efficiency of GPX, which could protect the cells against ROS (Fig. 4A) [40]. In the present study, the enzyme activity of intracellular GLR was found to increase with phenol concentration at different processing times, except in those cells treated with 3.0 $\mathrm{g} / \mathrm{l}$ phenol, at $6 \mathrm{~h}$ and $9 \mathrm{~h}$ (Fig. 4D). From the viewpoint of processing time, the cellular GLR activity after treatment for $9 \mathrm{~h}$ was higher than that after $3 \mathrm{~h}$ and $6 \mathrm{~h}$ in the presence of 0.0-2.0 g/l phenol. However, no GLR activity could be detected in cells treated with $3.0 \mathrm{~g} / \mathrm{l}$ phenol, at either $6 \mathrm{~h}$ or $9 \mathrm{~h}$ (Fig. 4D). The GSH content of cells treated with $2.0 \mathrm{~g} / \mathrm{l}$ and $3.0 \mathrm{~g} / \mathrm{l}$ phenol was lower than that in cells treated with less than $2.0 \mathrm{~g} / \mathrm{l}$ phenol at $3 \mathrm{~h}$. However, after $3 \mathrm{~h}$, the GSH content of cells treated with 0.0-2.0 g/l phenol rose rapidly after $6 \mathrm{~h}$ and $9 \mathrm{~h}$, and remained at a high level (Fig. 4E). In addition, we found that the GSH content remained at the same level in the presence of different concentrations of phenol after treatment for $6 \mathrm{~h}$ and $9 \mathrm{~h}$, except in the $3.0 \mathrm{~g} / \mathrm{l}$ phenol group (Fig. $4 \mathrm{E}$ ).

\section{Damage to chromatin and protection of chromosomal DNA}

In addition to DNA damage, ROS can cause nuclei to become less compacted and appear larger and more diffuse [41]. To monitor changes in the morphological structure of nuclei induced by ROS and/or phenol, the harvested cells were fixed and stained by a mixture of ethanol, ultrapure water, and DAPI (DNA specific dye). The structurally abnormal nuclear chromatin appeared larger and more diffuse, while the normal chromatin remained small and compacted (Fig. 5A). The percentage of cells with abnormal diffuse nuclear chromatin was recorded in order to investigate the severity of nuclear chromatin damage. At various time points, the non-phenol-treated and phenol-treated cells were harvested and stained with DAPI. As illustrated in Fig. 5B, the percentage of cells with nuclear chromatin disorganization remained at a low level (3.86\%-7.30\%) when phenol was present or absent, which implied that 0.0-3.0 g/l phenol did not cause obvious damage to DNA and chromatin.

The transcriptome data suggested that most of the genes participating in DNA replication and DNA repair showed significant upregulation in the presence of $2.0 \mathrm{~g} / \mathrm{l}$ phenol (Fig. 5C and 5D) (Additional File 3). In addition, genes encoding ribonucleoside-diphosphate reductase subunit M2 (CTRG_01327 and 
CTRG_01698), as well as genes encoding ribonucleoside-diphosphate reductase subunit M1 (CTRG_01309), were highly expressed in cells exposed to 1.0 and $2.0 \mathrm{~g} / \mathrm{l}$ phenol (Additional File 3). The encoded proteins of the above genes are small and large subunits of ribonucleotide reductase (RNR), which plays a crucial role in dNTP production and DNA synthesis [42]. Meanwhile, chromosome transmission fidelity protein 18 (CTRG_00975), which is essential for fidelity of chromosome transmission, was up-regulated by more than 4 -fold in the presence of both $1.0 \mathrm{~g} / \mathrm{l}$ and $2.0 \mathrm{~g} / \mathrm{l}$ phenol [43] (Additional File 3).

\section{Accumulation and degradation of unfolded and misfolded proteins}

External or internal ROS can cause the accumulation of unfolded or misfolded proteins in the endoplasmic reticulum (ER) lumen; a phenomenon known as ER stress (ERS) [37]. To monitor ROSinduced ER membrane damage, the phenol-treated cells were stained with the endoplasmic reticulum dye, ER-Tracker ${ }^{\mathrm{TM}}$ Red. For the observation, the ER structures of the viable cells were divided into three groups: normal (unfolded), abnormal shapes (folded and fragmented), and necrotic (Fig. 6A). When cells were exposed to $0.0 \mathrm{~g} / \mathrm{l}, 0.5 \mathrm{~g} / \mathrm{l}$, and $1.0 \mathrm{~g} / \mathrm{l}$ phenol, normal and abnormal ER structures were distributed in roughly $35 \%$ and $65 \%$ of cells at $3 \mathrm{~h}$, respectively (Fig. $6 \mathrm{C}$ ). Under the same conditions, there was no significant change in the ratio of cells containing normal and abnormal ER structures from $3 \mathrm{~h}$ to $9 \mathrm{~h}$, but there was a slight increase in the proportion of cells containing abnormal ER at $18 \mathrm{~h}$ (Fig. 6C). The necrotic cells and the cells containing abnormal ER accounted for a large share of the observed cells treated with high concentrations of phenol $(2.0 \mathrm{~g} / \mathrm{l}$ and $3.0 \mathrm{~g} / \mathrm{l})$ at various time points (Fig. $6 \mathrm{C})$. These results demonstrated that ER was not significantly injured by low concentrations of phenol $(0.5 \mathrm{~g} / \mathrm{l}$ and $1.0 \mathrm{~g} / \mathrm{l})$, but was markedly damaged by high concentrations of phenol $(2.0 \mathrm{~g} / \mathrm{l}$ and $3.0 \mathrm{~g} / \mathrm{l})$. In contrast, the recovery of cell growth in cells exposed to $2.0 \mathrm{~g} / \mathrm{l}$ phenol after $24 \mathrm{~h}$ suggested that certain mechanisms provided enough protein to retain homeostasis in the cells. Previous studies have demonstrated that, after the unfolded protein response (UPR) and autophagy, cells could recover homeostasis and normal ER function [44]. HSPs functioning as chaperones were implicated in the reversal of amino acid oxidation and refolding of denatured proteins resulting from the UPR [45-47]. The expression of one gene, annotated as 'small heat shock protein 21' (Hsp21) (CTRG_01443), was upregulated by 11.3-, 64-, and 13.9-fold change in the presence of $0.5 \mathrm{~g} / \mathrm{l}, 1.0 \mathrm{~g} / \mathrm{l}$, and $2.0 \mathrm{~g} / \mathrm{l}$ phenol, respectively (Additional File 4). Besides that, the gene CTRG_04372 annotated as co-chaperones in the Hsp70/Hsp90 family was significantly upregulated in the presence of $2.0 \mathrm{~g} / \mathrm{l}$ phenol (Additional File 4). Autophagy, as a conserved trafficking pathway, delivered unfolded or misfolded proteins, components, and organelles from the cytoplasm to the vacuole for degradation and recycling [44]. Four pivotal steps, including the activation of autophagy, the formation of the autophagosome, the cytoplasm-to-vacuole targeting (CVT) pathway, and vacuole fusion, ensured the effective degradation of the contents by vacuole hydrolases $[44,48,49]$. In the presence of $2.0 \mathrm{~g} / \mathrm{l}$ phenol, it was found that the expression of genes IRE1, ATG11, ATG23, and ATG25, related to the activation of autophagy and the formation of the 
autophagosome, were up-regulated by more than 2-fold (Additional File 4). However, APE1 and AMS1, which are related to autophagy, showed down-regulation by 2 -fold (Additional File 4).

The vacuole plays a key role in autophagy for the degradation and recycling of unfolded or misfolded proteins [48]. Therefore, Yeast Vacuole Membrane Marker MDY-64 was adopted to stain the vacuole membrane for visualizing changes in vacuole morphology in the non-phenol-treated and phenol-treated cells. The observation revealed vacuoles in different configurations that could be classified as follows: a single large vacuole, two to four medium-sized vacuoles, and massively fragmented vacuoles (Fig. 6B). After treatment for $3 \mathrm{~h}$, compared with the other treatments, $75 \%$ of cells treated with $0.5 \mathrm{~g} / \mathrm{l}$ phenol contained a single large vacuole. A single large vacuole was also predominant in cells treated with 1.0 and $2.0 \mathrm{~g} / \mathrm{I}$ phenol (71\% and 68\%, respectively) (Fig. 6D). In the same processing time, cells treated with non-lethal doses of phenol $(0.5 \mathrm{~g} / \mathrm{l}, 1.0 \mathrm{~g} / \mathrm{l}$, and $2.0 \mathrm{~g} / \mathrm{l})$ exhibited a lower proportion of fragmented vacuoles than untreated cells (Fig. 6D). At $9 \mathrm{~h}$ after treatment, cells treated with $1.0 \mathrm{~g} / \mathrm{l}$ phenol (49\%) showed the highest proportion of single large vacuoles, followed by cells treated with $0.5 \mathrm{~g} / \mathrm{l}$ phenol (40\%) (Fig. 6D). From these observations, we speculated that low concentrations of phenol suppressed the fragmentation of the cellular vacuole. However, the cells treated with $2.0 \mathrm{~g} / \mathrm{l}$ and $3.0 \mathrm{~g} / \mathrm{I} \mathrm{phenol}$ exhibited a higher proportion of fragmented vacuoles than the untreated cells, after treatment for both $9 \mathrm{~h}$ and $18 \mathrm{~h}$ (Fig. 6D). Since mutation of VAC8 has been correlated with vacuole fragmentation [49], we speculated that the above results might be related to downregulation of VAC8 (Additional File 4).

\section{Accumulation of fatty acid}

The KEGG pathway enrichment analysis revealed downregulation of 13 genes involved in fatty acid degradation (Fig. 7). In this pathway, long-chain acyl-CoA synthetase (EC: 6.2.1.3) is responsible for the degradation of hexadecanoate (fatty acid), and the corresponding genes, CTRG_02563 and CTRG_05500, were downregulated by 11.3- and 7-fold in response to $2.0 \mathrm{~g} / \mathrm{l}$ phenol, respectively (Fig. 7). When hexadecanoyl-CoA was converted into trans-hexadec-2-enoyl-CoA, the expression of the corresponding genes (CTRG_02374, CTRG_02377, CTRG_02721, and CTRG_05958), annotated as acyl-CoA oxidase (EC:

1.3.3.6) and acyl-CoA dehydrogenase (EC: 1.3.8.7), showed 147-, 12.1-, 2.8- and 5.7-fold decreases in cells treated with $2.0 \mathrm{~g} / \mathrm{I}$ phenol, respectively (Fig. 7). The genes CTRG_01068 and CTRG_02168, which encode acetyl-CoA acyltransferase1 (2.3.1.16), were 7- and 3.7-fold downregulated in cells treated with $2.0 \mathrm{~g} / \mathrm{l}$ phenol (Fig. 7). In addition, the differential expression analysis implicated genes encoding aldehyde dehydrogenase (1.2.1.3) and alcohol dehydrogenase (1.1.1.1) in the conversion of fatty acid to alcohol (Fig. 7). Specifically, CTRG_05836, CTRG_00882, CTRG_05482, CTRG_01329, and CTRG_05010 were significantly downregulated in response to $2.0 \mathrm{~g} / \mathrm{l}$ phenol exposure (Fig. 7). These results suggest that decreased fatty acid degradation efficiency, caused by the downregulation of expression of related genes, may serve to elevate the intracellular fatty acid content or change the fatty acid component in cells $[13$, 50]. 


\section{Other tolerance mechanisms}

Previous studies have found that cell-wall remodeling can lead to increased ethanol resistance in yeast [51]. Our comparative transcriptome analysis revealed >twofold upregulation of six genes related to cellwall biogenesis and integrity in response to 1.0 and $2.0 \mathrm{~g} / \mathrm{l}$ phenol, including CTRG_05721, CTRG_05949, CTRG_00608, CTRG_00036, CTRG_01855, and CTRG_03473 (Additional File 5). We therefore reasoned that genes involved in cell-wall biogenesis may contribute to the increased resistance of $C$. tropicalis SHC03 to phenol. A series of differential expression analyses of genes upregulated in response to $2.0 \mathrm{~g} / \mathrm{l}$ phenol revealed enrichment in the chitin synthesis pathway (Fig. 8A; Additional File 5). As illustrated in Fig. 8A, during the conversion of glucose to chitin, the expression levels of CTRG_00414, CTRG_00601, CTRG_01436, CTRG_03651, CTRG_03585, CTRG_05721, and CTRG_05949 were markedly increased. In addition, only two proteins are known to play a reverse role in the chitin synthesis pathway, and their encoding genes (CTRG_03727 and CTRG_03728) were downregulated by 23.4- and 13.6-fold, respectively (Fig. 8A; Additional File 5). In addition, most of the genes in the chitin degradation pathway (chitin to chitobiose or N-Acetyl-D-glucosamine), including CTRG_05456 and CTRG_05827 (encoding chitinase) and CTRG_01063 (encoding beta-N-acetylhexosaminidase), were significantly downregulated in expression (Fig. 8A; Additional File 5). In the process of converting chitin to chitosan, CTRG_01049, which encodes chitin deacetylase, was dramatically upregulated; by 26.5-fold (Fig. 8A; Additional File 5). Therefore, we speculated that the up- and down-regulated expression of these genes probably served to increase the accumulation of chitin and chitosan in the cell wall. To confirm the increased phenol tolerance of cells that had undergone cell wall remodeling, we conducted cell-wall susceptibility analyses of the phenol-treated and non-phenol-treated cells using lytic enzyme, a $\beta-1,3-g l u c a n a s e$ from Arthrobacter luteus [51]. After incubation in media supplemented with different concentrations of phenol for $3 \mathrm{~h}, 9 \mathrm{~h}$, and $18 \mathrm{~h}$ at $30^{\circ} \mathrm{C}$, cells were isolated for cell-wall susceptibility analysis. After $3 \mathrm{~h}$, the cell density $\left(O D_{600}\right)$ of samples treated with 0.0 and $0.5 \mathrm{~g} / \mathrm{l}$ phenol decreased significantly upon addition of lyticase to the medium. This decrease was even more pronounced in cells treated with $1.0 \mathrm{~g} / \mathrm{l}$ phenol and $3.0 \mathrm{~g} / \mathrm{l}$ phenol, decreasing to less than $10 \%$ of the initial cell density at $4 \mathrm{~h}$ (Fig. 8B). The cell density of samples treated with $2.0 \mathrm{~g} / \mathrm{l}$ phenol dropped slowly after lyticase was added into the medium for $4 \mathrm{~h}$, decreasing to about $65 \%$ at $4 \mathrm{~h}$ (Fig. 8B). After treatment with phenol for $9 \mathrm{~h}$, the samples in $0.0 \mathrm{~g} / \mathrm{l}$ and $0.5 \mathrm{~g} / \mathrm{l}$ phenol still displayed the most rapid cell-density decline in the lyticase-supplemented medium; the decrease in cell density in these samples was greater than the cell-density decrease seen in the samples in 1.0-3.0 g/l phenol (Fig. 8C). However, the cell density of the sample in $3.0 \mathrm{~g} / \mathrm{l}$ phenol dropped more quickly than all of the others, at $3 \mathrm{~h}$ (Fig. $8 \mathrm{C}$ ). The resistance of cells to lyticase after treatment with 1.0 $\mathrm{g} / \mathrm{l}$ and $2.0 \mathrm{~g} / \mathrm{l}$ phenol for $9 \mathrm{~h}$ was similar to that of cells treated with the corresponding concentration of phenol for $3 \mathrm{~h}$ (Fig. 8C). In cells exposed to phenol for $18 \mathrm{~h}$, the cell density of the sample treated with 3.0 $\mathrm{g} / \mathrm{l}$ phenol descended sharply, decreasing to about $12 \%$ after addition of lyticase to the medium and incubation for $4 \mathrm{~h}$ (Fig. 8D). The cell density of samples treated with $1.0 \mathrm{~g} / \mathrm{l}$ and $2.0 \mathrm{~g} / \mathrm{l}$ phenol for 18 hours dropped slowly after the 4-h lyticase treatment. In contrast, the cell density in the samples with 0.0 $\mathrm{g} / \mathrm{l}$ and $0.5 \mathrm{~g} / \mathrm{l}$ phenol showed no significant decline (Fig. 8D). The above results demonstrated that treatment for $3 \mathrm{~h}$ and $9 \mathrm{~h}$ with 1.0-3.0 $\mathrm{g} / \mathrm{l}$ phenol induced increased resistance of cells to lyticase, with a 
maximal effect seen at $2.0 \mathrm{~g} / \mathrm{l}$ phenol. While $2.0 \mathrm{~g} / \mathrm{l}$ phenol appeared to be the optimal concentration for lyticase resistance, cells treated with $0.0 \mathrm{~g} / \mathrm{l}$ and $0.5 \mathrm{~g} / \mathrm{l}$ phenol also exhibited significantly increased resistance to lyticase after $18 \mathrm{~h}$. However, cells treated with $3.0 \mathrm{~g} / \mathrm{l}$ phenol for $18 \mathrm{~h}$ showed decreased resistance to lyticase compared with this treatment after $3 \mathrm{~h}$ and $9 \mathrm{~h}$.

One important detoxification mechanism is the active efflux mechanism, which has been shown to reduce the level of intracellular toxic compounds, resulting in retention of the physiological activities of the cells [52]. The major facilitator superfamily (MFS) and ATP-binding cassette (ABC) subfamily are the two most important groups of multidrug/multixenobiotic resistance (MDR/MXR) transporters responsible for the efflux of toxic compounds $[53,54]$. In response to at least two concentrations of phenol, the MFS genes CTRG_03938, CTRG_00385, and CTRG_03729 showed a >2-fold increase in expression (Additional File 6). In particular, CTRG_00385 was up-regulated by 7 -fold, 18 -fold, and 169 -fold in response to $0.5 \mathrm{~g} / \mathrm{l}$, $1.0 \mathrm{~g} / \mathrm{l}$, and $2.0 \mathrm{~g} / \mathrm{l}$ phenol. Additionally, a statistical analysis of differential gene expression showed that 14 genes belonging to the MFS and ATP-binding cassette (ABC) subfamily exhibited greatly up-regulated expression in the presence of phenol (Additional File 6). As illustrated in Additional File 6, two, six, and ten transporter genes were significantly upregulated in response to $0.5 \mathrm{~g} / \mathrm{l}, 1.0 \mathrm{~g} / \mathrm{l}$, and $2.0 \mathrm{~g} / \mathrm{l}$ phenol, which indicated that the number of upregulated transporter genes increased with the rise in phenol concentration. Compared with tolerance mechanisms, detoxification mechanisms can contribute to the detoxification of the toxic compounds to less toxic or nontoxic compounds, improving the growing environment of the strains $[19,20]$. Previous studies have illustrated that phenol degradation is the vital detoxification mechanism of $C$. tropicalis in response to phenol [34,55]. From the point of view of the molecular mechanism, the biodegradation of phenol mainly relies on subsequent enzymatic steps via the $\beta$-ketoadipate pathway in C. tropicalis [33]. The crucial enzyme in this pathway, phenol 2-monooxygenase (EC 1.14.13.7), is responsible for the hydroxylation of phenol to catechol, which is a rate-limiting step [33] (Fig. 9). To date, two genes encoding phenol 2-monooxygenase, CTRG_00423 and CTRG_03102, have been discovered in $C$. tropicalis strains $\mathrm{JH} 8$ and MYA-3404, respectively $[32,56]$. In the present study, the comparative transcriptomics data did not indicate that CTRG_00423 and CTRG_03102 were significantly up-regulated under phenol stress after treatment for $3 \mathrm{~h}$ (Fig. 9). In the second step of the $\beta$-ketoadipate pathway, catechol 1,2-dioxygenase (EC 1.13.11.1) is responsible for the conversion of catechol to cis,cismuconate (Fig. 9). CTRG_01732 and CTRG_00171, encoding catechol 1,2-dioxygenase, were not significantly up-regulated in response to different concentrations of phenol (Fig. 9). The above results suggest that the phenol degradation mechanism of $C$. tropicalis SHC-03 was probably not activated.

\section{Discussion}

In this study, the growth status of cells showed that phenol could seriously influence the viability of cells as well as their fermentation efficiency (Fig. 1A). In particular, at $2.0 \mathrm{~g} / \mathrm{l}$ phenol, the lag phase extended for about $20 \mathrm{~h}$, but after that, the exposed cells recovered and returned to normal growth (Fig. 1A). This result indicated that tolerance and/or detoxification mechanisms were activated to protect the cells from the toxicity of phenol and retain the viability of cells through the stress period. To investigate these mechanisms, we conducted comparative transcriptome analysis and cellular analysis of non-phenol- 
treated and phenol-treated cells. We identified several up-regulated gene clusters. These clusters were correlated with DNA replication and repair, unfolded protein response, autophagy, cell-wall biogenesis, and efflux systems. Furthermore, we identified a series of significantly down-regulated genes related to the degradation of fatty acid. These results provided a new perspective towards a better understanding of tolerance and/or detoxification mechanisms utilized by fermenting strains in response to phenolics derived from lignocellulose biomass.

The degradation of phenol in $\mathrm{C}$. tropicalis via the $\beta$-ketoadipate pathway is the most important tolerance and detoxification mechanism utilized by $\mathrm{C}$. tropicalis in response to phenol [32-34, 55]. However, observation of phenol concentrations in different samples indicated that C. tropicalis SHC-03 did not degrade phenol in YPD medium. Based on the transcriptome analysis of key genes (CTRG_00423, CTRG_03102, CTRG_01732, and CTRG_00171) in the $\beta$-ketoadipate pathway, we found that these genes were not up-regulated under phenol stress (Fig. 9). Thus, we confirmed that phenol did not stimulate the degradation mechanism of $\mathrm{C}$. tropicalis in YPD medium, which conflicted with the result from $\mathrm{C}$. tropicalis grown in culture medium with phenol as sole carbon source [55]. Previous studies have found that the efficiency of phenol degradation is repressed by competitive inhibition from glucose in medium containing more than $600 \mathrm{mg} / \mathrm{I}$ glucose [57]. We therefore considered that the competitive inhibition caused by a high concentration of glucose $(20,000 \mathrm{mg} / \mathrm{l})$ in YPD medium probably blocked the degradation of phenol by $\mathrm{C}$. tropicalis SHC-03. Due to the lack of activation of a detoxification mechanism, the resistance mechanism of $\mathrm{C}$. tropicalis to phenol plays a critical role in maintaining the viability of phenol-treated cells.

Previous studies have found that phenolics can induce increased membrane permeability, including decreased cell membrane lipid-to-protein ratios and dysfunction of the mitochondrial membrane [9-11]. Then, the mitochondrial dysfunction will produce exogenous ROS and induce ROS accumulation [35]. In the present study, the results from the mitochondrial damage and the determination of ROS content further supported the contentions mentioned above (Fig. 3). We found that, after phenol treatment for $3 \mathrm{~h}$, the treated cells exhibited serious damage to the mitochondrial membrane and high-level accumulation of ROS, which can induce damage to DNA, proteins, lipids, and the cytoskeleton (Fig. 3) [37-39]; the accumulation of ROS can seriously affect the physiological and biochemical functions of cells. Interestingly, in the presence of $2.0 \mathrm{~g} / \mathrm{l}$ (or lower) phenol, the percentages of the cells accumulating ROS declined to a lower level at $9 \mathrm{~h}$ (Fig. 3D), which illustrated that potential molecular mechanisms were active and contributed to the scavenging and/or decreased production of intracellular ROS.

Since enzymatic and non-enzymatic antioxidant defense systems were found to be responsible for the scavenging of excessive ROS [36], we carried out an expression analysis of the genes related to antioxidant defense systems, such as SOD, GPX, CTT, GLR, and so on, at the transcriptional level. The results showed that most of these genes were not up-regulated in response to $3 \mathrm{~h}$ exposure to several concentrations of phenol (Additional File 2), which implied that these antioxidant defense systems were not activated at the transcriptional level in response to treatment for $3 \mathrm{~h}$. To clarify the mechanism related to the scavenging of the intracellular ROS between $3 \mathrm{~h}$ and $9 \mathrm{~h}$, the activity assays of SOD, GPX, CTT, and 
GLR, as well as determination of GSH content, were conducted (Fig. 4). As illustrated in Fig. 4, the activities of SOD, GPX, and GLR showed obvious changes correlating with different conditions (phenol concentration and processing time). These changes were distinct from those at the transcriptional level. We hypothesized that differing regulation at the translational level might lead to the above inconsistent findings. The results from the SOD activity assays revealed that SOD contributes to the dismutation of $\mathrm{O}_{2}{ }^{-}$while scavenging ROS after treatment with phenol for $3 \mathrm{~h}$ and $6 \mathrm{~h}$, and that SOD activity increased with elevation of phenol concentration. However, the SOD activities in different treatments were very low at $9 \mathrm{~h}$. This implies that most of the $\mathrm{O}_{2}{ }^{-}$probably had been converted to $\mathrm{H}_{2} \mathrm{O}_{2}$, and the SOD activity at this time was sufficient to retain homeostasis of intracellular ROS at a low level. During the conversion of $\mathrm{H}_{2} \mathrm{O}_{2}$ to $\mathrm{H}_{2} \mathrm{O}, \mathrm{GPX}$ activities in the treatments with $1.0 \mathrm{~g} / \mathrm{l}$ and $2.0 \mathrm{~g} / \mathrm{l}$ phenol exhibited a dramatic increase, but CTT activity was not detected in any of the treatments, implying that GPX played an important role in the reduction of $\mathrm{H}_{2} \mathrm{O}_{2}$ after treatment with phenol for $6 \mathrm{~h}$ and $9 \mathrm{~h}$. Additionally, the high activity of GLR guarantees sufficient supplementation of GSH activity to contribute to the reduction of $\mathrm{H}_{2} \mathrm{O}_{2}$ catalyzed by GPX at $6 \mathrm{~h}$ and $9 \mathrm{~h}$ (Fig. 4D). In summary, the up-regulation of intracellular SOD activity (involved in the dismutation of $\mathrm{O}_{2}^{-}$) at $3 \mathrm{~h}$ and $6 \mathrm{~h}$, and the up-regulation of intracellular GPX activity (involved in the reduction of $\mathrm{H}_{2} \mathrm{O}_{2}$ ) at $6 \mathrm{~h}$ and $9 \mathrm{~h}$, promoted the detoxification of endogenous ROS induced by phenol and low-level intracellular ROS.

Our results indicated massive accumulation of ROS in the phenol-treated cells after treatment for $3 \mathrm{~h}$. The accumulation of ROS can induce DNA damage. Recent studies have classified ROS-induced DNA damage as falling mainly into the categories of single- or double-strand breakage, base modifications, and deoxyribose modification, the untimely repair of which could lead to cell death, replication errors, mutations, and genomic instability [35]. Thus, we carried out morphological structure analysis of nuclei using DAPI under phenol stress. The results of this analysis demonstrated that phenol did not induce significant chromatin damage when the concentration of phenol was climbing (Fig. 5A, B; Additional File 3). Since chromatin protection mechanisms are associated with the DNA damage response [58], we speculated that ROS did not cause serious DNA damage. Given the transcriptome data, at $2.0 \mathrm{~g} / \mathrm{l}$ phenol, a series of genes, responsible for DNA repair, DNA synthesis, dNTP production, and chromatin protection, were significantly up-regulated in the C. tropicalis SHC-03 (Fig. 5C, D; Additional File 3). Thus, we surmised that up-regulated expression of these genes probably played a key role in protecting DNA, dNTPs, and chromatin from damage by ROS, and contributed to the maintenance of the viability of cells and the increased tolerance of $\mathrm{C}$. tropicalis SHC-03 to phenol. Additionally, phenolic compounds (luteolin and quercetin) as antioxidants have been found to significantly decrease DNA damage [59]. Perhaps phenol can function in a similar manner to luteolin or quercetin, helping cells to retain DNA and chromatin homeostasis.

Phenol-induced redox imbalance and ROS-induced protein damage can also cause unfolded or misfolded proteins to accumulate in the ER lumen and thereby induce ER stress (ERS) [37,44]. Apparently, the high concentration of phenol $(2.0 \mathrm{~g} / \mathrm{l})$ caused serious damage to the ER at 3-18 h after treatment (Fig. $6 \mathrm{C})$. In contrast, the recovery of cell growth in the presence of $2.0 \mathrm{~g} / \mathrm{l}$ phenol suggested that several pathways 
(unfolded protein response, UPR) were triggered by ERS to guarantee the refolding of unfolded protein, the degradation of misfolded proteins, the restoration of normal ER function, and the maintenance of cell survival [44]. Two key fundamental pathways have been associated with response to ERS: one based on chaperone proteins and the other based on autophagy [44]. Previous studies have shown that HSPs can act as molecular chaperones associated with the folding, trafficking, protection, and renaturation of cellular proteins that have undergone the heat shock response $[60,61]$. In the present study, the CTRG_01443 gene, annotated as Hsp21, and the CTRG_04372 gene, annotated as co-chaperone of the Hsp70/Hsp90 family, were up-regulated by more than 2-fold in the presence of phenol (Additional File 4). It has been previously established that the up-regulation of the genes in the Hsp70/Hsp90 family is implicated in the adaptation and resistance of $\mathrm{C}$. albicans to stress, conferred by proteasomal degradation of chaperoned client proteins $[47,62]$. Thus, we hypothesized that the accumulation of these HSPs serves to protect the cellular proteins and facilitate the degradation of misfolded proteins via the ubiquitin proteasome system and relieve ERS, thereby improving phenol resistance in C. tropicalis SHC03. Additionally, UPR can activate 27 autophagy-related genes (ATG) which control autophagy in S. cerevisiae [48]. These genes can be grouped into the functional categories of non-selective autophagy (17 genes), selective autophagy (7 genes), and degradation of autophagic bodies (2 genes) [48]. In the present study, the transcriptome data showed that, with the exception of ATG11, ATG23, and ATG25, there were no marked changes in the expression levels of these ATGs. In addition, expression of the hydrolase genes APE1 and AMS1, the encoded proteins of which are specifically transported by autophagy and the CVT pathway (a type of selective autophagy) to the vacuole for hydrolyzation of proteins [63], was downregulated at $3 \mathrm{~h}$ after the phenol treatment. We also surveyed the expression of genes belonging to the PERK-elF2a pathway, ATF6, IRE1, ATF4, and CHOP, which have been associated with the induction and regulation of autophagy and chaperones [44]. Only IRE1 (CTRG_04146) showed a change in expression; its expression was up-regulated by more than 2 -fold in the presence of $2.0 \mathrm{~g} / \mathrm{l}$ phenol at $3 \mathrm{~h}$. In summary, compared with autophagy, HSP-mediated proteasomal degradation played the more dominant role in the relief of ERS triggered by phenol at the early stage of treatment.

As a compartmentalized organelle, the vacuole contains a series of hydrolases which can degrade damaged or unfolded proteins from the cytoplasm in S. cerevisiae during autophagy [63]. It has been found that increased vacuolar volume (or the fusion of a fragmented vacuole) can sufficiently improve the hydrolytic capacity for autophagy [64]. Our morphological observation demonstrated that the proportion of cells containing large vacuoles at low concentrations of phenol $(0.5 \mathrm{~g} / \mathrm{l}$ and $1.0 \mathrm{~g} / \mathrm{l}$ phenol) was higher than that in control cells at $3 \mathrm{~h}$ and $9 \mathrm{~h}$, and the proportion of cells containing large vacuoles at $2.0 \mathrm{~g} / \mathrm{l}$ phenol was similar to that of the untreated group at $3 \mathrm{~h}$ (Fig. 6D). These results implied that low concentrations of phenol might block the fragmentation of the cellular vacuole in order to allow the cell to retain efficient autophagy. Unfortunately, the results from RNA-seq demonstrated that the expression of the genes TORC1, SIT4, and VPS1, which regulate the fragmentation or fusion of the vacuole, did not significantly change under phenol stress at $3 \mathrm{~h}$ (data not shown). Perhaps several unknown genes involved in vacuole fusion were responsible for the higher proportion of cells containing large vacuoles. Therefore, a follow-up study will be conducted to characterize these genes. However, we did find that the 
proportion of cells containing large vacuoles was lower in the cells treated with $2.0 \mathrm{~g} / \mathrm{l}$ phenol than in the untreated cells, at $9 \mathrm{~h}$ and $18 \mathrm{~h}$ (Fig. 5D). As the knockout of VAC8 (CTRG_04061) has been shown to cause fragmentation of vacuoles [49], our results can probably be attributed to significant downregulation of VAC8 (Additional File 4).

As a basic cellular component, fatty acid is involved in the formation of lipid membranes and the storage of metabolic energy [65]. In the present study, the expression of most of the genes related to the synthesis of fatty acid showed no distinct change, but most of the genes belonging to the fatty acid degradation pathway exhibited down-regulation in the presence of $2.0 \mathrm{~g} / \mathrm{l}$ phenol (Fig. 7). These results indicate that fatty acids probably accumulate in phenol-treated cells, which would contribute to the regeneration and repair of organelles within the membrane system. In addition, changes in the composition of membrane fatty acids could increase the tolerance of S. cerevisiae to a mixture of acetic acid, furfural, and phenol [66]. It has also been discovered that the increased synthesis of fatty acid can elevate phenol tolerance in an evolved Chlorella strain [13]. Therefore, we speculated that the increased tolerance of C. tropicalis to high concentrations of phenol was likely related to the accumulation of fatty acid. Interestingly, the accumulation of fatty acids was found to be associated with the fragmentation of the vacuole [65]. This might explain how the proportion of cells containing fragmented vacuoles when exposed to under $2.0 \mathrm{~g} / \mathrm{l}$ phenol stress was higher than that in the untreated samples at $9 \mathrm{~h}$ and $18 \mathrm{~h}$.

Given the transcriptome data, we found that phenol might stimulate chitin accumulation in the cell wall, which could lead to cell wall remodeling (Fig. 8A; Additional File 5). Since chitin is a structural microfibrillar component and is associated with cell wall rigidity $[67,68]$, it might be the case that the accumulation of chitin in cell walls promotes the adaptation of cells to hypo-osmotic conditions, increases the resistance of cells to stress, reduces the production of intracellular ROS, and prevents the entrance of phenol into the cells $[69,70]$. In our study, we found that the cells treated with $1.0 \mathrm{~g} / \mathrm{l}, 2.0 \mathrm{~g} / \mathrm{l}$, and $3.0 \mathrm{~g} / \mathrm{l}$ phenol (MHT) exhibited higher lyticase tolerance than those treated with $0.0 \mathrm{~g} / \mathrm{l}$ and $0.5 \mathrm{~g} / \mathrm{l}$ phenol (LT), after treatment with phenol for $3 \mathrm{~h}$ to $9 \mathrm{~h}$ (Fig. 8B, C). This implied that phenol can induce cell wall remodeling, and thereby increase the cells' resistance to stress. However, it remains to be studied whether it was the accumulation of chitin induced by phenol, and related to cell wall remodeling, that improved the phenol resistance of $\mathrm{C}$. tropicalis. Besides, it was found that the lyticase tolerance of $\mathrm{LT}$ cells exposed to phenol for $18 \mathrm{~h}$ was higher than the tolerance of MHT cells for $18 \mathrm{~h}$, which possibly can be attributed to the raised tolerance of LT cells in stationary phase [71]. As shown in Fig. 8, the cells treated with $3.0 \mathrm{~g} / \mathrm{l}$ phenol showed a rapid decline in lyticase resistance from $3 \mathrm{~h}$ to $18 \mathrm{~h}$, compared with cells treated with $1.0 \mathrm{~g} / \mathrm{l}$ and $2.0 \mathrm{~g} / \mathrm{l}$ phenol. This is probably related to cell death induced by high concentrations of phenol.

Another detoxification mechanism is the efflux of external drugs and cytotoxic compounds catalyzed by MDR/MXR transporters [52]. This mechanism can enable the cell to retain the intracellular drug/xenobiotic concentration at low levels and maintain the viability of cells under stress from these toxic compounds [53, 54, 72-74]. In our study, at different concentrations of phenol, 14 genes encoding MDR/MXR transporters, which belong to the ABC superfamily and MFS, showed significantly up- 
regulated expression (Additional File 6). Additionally, as the phenol concentration increased, the upregulated transporter genes became more numerous. Based on these results, we reasoned that there were definite connections between an active efflux mechanism and the tolerance and response of $C$. tropicalis to phenol. Among these genes, CTRG_00385, annotated as 'MFS antiporter QDR1', was significantly upregulated in the presence of different concentrations of phenol. This supports the idea that its encoded protein might play a key role in the efflux of phenol and endogenous toxic metabolites from cell damage caused by phenol and ROS [74]. As the function of the encoded protein of this gene was not characterized, we plan to conduct research investigating its function in the future. In S. cerevisiae, QDR1 (YIL120W), a multidrug transporter from the MFS, modulates the assembly of the outer spore wall and is responsible for resistance to quinidine, ketoconazole, and fluconazole $[75,76]$. Additionally, as illustrated in Fig. 8A, CTRG_01049, which encodes chitin deacetylase, an enzyme that catalyzes the conversion of chitin to chitosan, was up-regulated by 26.5 -fold. Since the spore wall is primarily composed of chitosan $[77,78]$, up-regulated expression of CTRG_01049 should lead to excess accumulation of chitosan in the spore wall. Since mature spores, as quiescent cells, exhibit resistance to organic solvents, heat, and digestive enzymes, and since chitosan and dityrosine layers of the spore wall prominently contribute to stress resistance, a hypothesis has been proposed that sporulation of $\mathrm{C}$. tropicalis is activated in order to reduce the insult of phenol to cells [79-81]. However, according to eosin $Y$ staining method [75], we observed no spores in the samples at 3,9 , and $18 \mathrm{~h}$ after cells were exposed to different concentrations of phenol (data not shown). This suggests the possible need for further exploration of the mechanisms underlying sporulation in $\mathrm{C}$. tropicalis.

\section{Conclusions}

In this research, C. tropicalis SHC-03 cells were treated with phenol as a representative of phenolics. Cell growth data from cells treated with phenol revealed that a series of tolerance mechanisms played dominant roles in the resistance of $\mathrm{C}$. tropicalis to phenol. These mechanisms, however, did not include phenol degradation; no phenol degradation was detected. The experimental results indicated that phenol can induce massive accumulation of ROS. Although these intracellular ROS were found to be scavenged by SOD and GPX, the accumulation of ROS in the early stage after phenol treatment could induce damage to DNA, proteins, and lipids [37-39] (Fig. 10), and this stress could lead to morphological changes in the structure of the endoplasmic reticulum and vacuole (Fig. 10). To reduce this damage, a series of protection mechanisms were activated. For example, a system of DNA repair and synthesis serves to ensure the stability of heredity, and key enzymes retain the fidelity of chromosome transmission and the stability of chromosomal structure (Fig. 10). HSP-mediated proteasomal degradation and autophagy served to maintain intracellular protein homeostasis and accelerated recycling of proteins (Fig. 10). Additionally, the accumulation of fatty acids contributed to the regeneration and repair of organelles with membrane systems (Fig. 10). Cell wall remodeling minimized both import of phenol into the cells and production of intracellular ROS (Fig. 10). The MXR/MDR transporters facilitated export of phenol and cytotoxic compounds from the cells, and maintained the intracellular drug concentration at low levels in order to maintain cell viability (Fig. 10). This is the first study to shed light on the influence of 
phenolics generated from lignocellulose hydrolysate on the physiological characteristics of $\mathrm{C}$. tropicalis SHC-03 and explore its tolerance mechanism to phenol stress.

\section{Methods}

\section{Yeast growth conditions and reagents}

C. tropicalis SHC-03, isolated from a winery in She Hong, was grown in YPD medium ( $\mathrm{w} / \mathrm{v}, 1 \%$ yeast extract, $2 \%$ peptone, and $2 \%$ glucose) and in YPD medium supplemented with $0.5 \mathrm{~g} / \mathrm{l}, 1.0 \mathrm{~g} / \mathrm{l}, 2.0 \mathrm{~g} / \mathrm{l}$ and $3.0 \mathrm{~g} / \mathrm{l}$ phenol with $200 \mathrm{rpm}$ shaking at $30^{\circ} \mathrm{C}$. With non-phenol-treated culture as control, the pre-cultures were cultivated in YPD medium until the cell density (the absorbance at $600 \mathrm{~nm}$ wavelength, $O D_{600}$ ) was 4.0, then harvested by centrifugation at $4,000 \mathrm{rpm}$ for $3 \mathrm{~min}$ at $4{ }^{\circ} \mathrm{C}$, and inoculated into $50 \mathrm{ml}$ flasks with phenol-added YPD medium. Aliquots of cells and supernatant were harvested for analysis at various time points from $0 \mathrm{~h}$ to $72 \mathrm{~h}$. Cell density $\left(O D_{600}\right)$ of the cultures was determined by using a UV-2802 spectrophotometer (Unico, NJ, USA). Media ingredients were purchased from Sigma-Aldrich (St. Louis, MO, USA) or Sangon Biotech (Shanghai, China).

\section{Determination of Phenol degradation rate}

The concentration of residual phenol was determined by the 4-aminoantipyrine spectrophotometric method. The reaction among phenol, 4-aminoantipyrine and potassium ferricyanide will develop a red color under alkaline conditions which can be measured by reading the absorbance at $510 \mathrm{~nm}\left(O D_{510}\right)$.

\section{qRT-PCR assays}

To confirm the accuracy of results from RNA-seq, the qRT-PCR assay of the isolated mRNA for RNA-seq were implemented on a Mastercycler ${ }^{\circledR}$ EP Realplex system (Eppendorf, Hamburg, Germany), using the procedures reported previously [82]. A FastQuant RT Kit (With gDNase) and a Real Master Mix (SYBR Green) Kit (Tiangen Biotech Co., Ltd) were respectively exploited to synthesize the first-strand cDNA and quantitative PCR reactions. Before qRT-PCR reactions were carried out, a calibrated messenger RNA (mRNA) control mix, which was gifted by Z. Lewis Liu (Bioenergy Research, NCAUR-ARS, US Department of Agriculture, Peoria, IL, USA), was integrated into the reaction system as a reference. Using online software of primer3 (http://bioinfo.ut.ee/primer3-0.4.0/primer3/), the primers of the selected genes were designed for qRT-PCR assay (Additional file 7). In the qRT-PCR reactions, three biological replicates and three technical replicates were performed, and the acquired data was analyzed using the developed methods [83].

\section{RNA-Seq and analysis}

After the pre-cultured cells of $C$. tropicalis SHC-03 were transferred into the YPD mediums with different concentration of phenol, the phenol-treated cells and the non-phenol-treated cells were obtained at $3 \mathrm{~h}$ for RNA-Seq. RNA-Seq was conducted by Biomarker Technology Co. Ltd (Beijing, China) with Hiseq-PE150 
(Illumina, Inc. San Diego, CA United States). Based on the sequence of C. tropicalis MYA-3404 as reference genome, we analyzed the raw data by the BMKCloud cloud server (http://www.biocloud.net). The gene expression levels were analyzed using fragments per kilobase of the transcript per million mapped (FPKM) method [84]. Differential expression analysis of two samples with three biological replicates was performed using the DEGseq $\mathrm{R}$ package [82] in a threshold criterion of the value of $\mid \log _{2}$ (fold change) $\mid \geq 1$ (FDR < 0.05). The annotations of differentially expressed genes (DEGs) were performed by the COG [85], GO [86], KEGG [87], KOG [88], Swiss-Prot [89], Pfam [90], NR [91] databases. We performed the statistical tests to identify the DEGs enriched in different KEGG pathways using KOBAS software [92].

\section{Fluorescence microscopy and cellular analysis}

The fluorescence microscopy, an Axio Imager A2 microscope (Carl Zeiss AG, Oberkochen, Germany) equipped with DIC, GFP, Rhod and DAPI filter lens, was used to observe the integrity of the cellular structures to evaluate the accumulation of ROS, nuclear chromatin disorganization, mitochondrial membrane damage, endoplasmic reticulum membrane damage, and vacuole membrane damage. Before the harvested cells were stained by various dyes, all the reagents and buffers have been preheated at 30 ${ }^{\circ} \mathrm{C}$. To ensure the accuracy of experiment results, at least 100 cells were examined on each bright-field image.

To detect the reactive oxygen species (ROS), $10 \mu \mathrm{g}$ of 2' 7'-dichlorofluorescein diacetates (DCFH-DA) (Sigma-35845) (using a $2.5 \mathrm{mg} / \mathrm{ml}$ stock in ethanol) was added into $10^{7}$ cells. After a 2-h incubation at $30^{\circ} \mathrm{C}$, cells were washed twice with ultrapure water, and resuspended in $0.1 \mathrm{ml}$ phosphate buffered solution (PBS) pH 7.0 [43]. Cells was observed using the GFP filter lens.

To visualize DNA chromatin, $10^{7}$ cells were collected and washed twice with ultrapure water. To fix and stain the harvested cells, cells were resuspended by $1 \mathrm{ml}$ of the mixture of ethanol and ultrapure water $(\mathrm{v} / \mathrm{v}, 19: 1)$, which had been blended with $1 \mu \mathrm{l}$ of a $100 \mu \mathrm{g} / \mathrm{ml}$ diaminophenylindole (DAPI) (Sangon Biotech-E607303-0002). After resuspension, these suspensions were immediately centrifuged at 8,000 rpm for $1 \mathrm{~min}$, and the depositions were washed twice with ultrapure water and resuspended in $0.1 \mathrm{ml}$ PBS pH 7.0. Cells was observed using the DAPI filter lens.

To investigate the mitochondrial membranes of the phenol-treated cells, $10^{7}$ cells incubated with Mito Tracker $^{\mathrm{TM}}$ Green FM (Thermo Fisher Scientific-M7514) $(100 \mathrm{nM})$ at $30^{\circ} \mathrm{C}$ for $15-45 \mathrm{~min}$. After staining, the cultures were centrifuged at 8,000 rpm for $1 \mathrm{~min}$, and the supernatants were discarded. The collected cells were washed twice with ultrapure water, and resuspended in $0.1 \mathrm{ml} \mathrm{PBS} \mathrm{pH} \mathrm{7.0.} \mathrm{Cells} \mathrm{was} \mathrm{observed}$ using the GFP filter lens.

To monitor the morphological change of the ER induced by phenol stress, $1 \mu \mathrm{l}$ of a $1 \mathrm{mM}$ ER-Tracker ${ }^{\mathrm{TM}}$ Red (Thermo Fisher Scientific-E34250) was added into $10^{7}$ cells, which had been washed twice with sterile deionized water and resuspended in $1.0 \mathrm{ml}$ PBS pH 7.0. After incubation at $30^{\circ} \mathrm{C}$ for $15-30 \mathrm{~min}$, the 
stained cells were washed with sterile deionized water, and resuspended in $0.1 \mathrm{ml} \mathrm{PBS} \mathrm{pH} \mathrm{7.0.} \mathrm{Cells} \mathrm{was}$ observed using the Rhod filter lens.

$10^{7}$ cells were harvested and stained by Yeast Vacuole Membrane Marker MDY-64 (Thermo Fisher Scientific-Y7536) for visualizing the vacuole morphology. The cells were incubated at $30{ }^{\circ} \mathrm{C}$ for a maximum of 3-5 min. The cells were pelleted by centrifugation and resuspended in $0.1 \mathrm{ml} \mathrm{PBS} \mathrm{pH} \mathrm{7.0.}$ Cells was observed using the GFP filter lens.

\section{Determination of intracellular SOD, CTT, GPX, GLR activity and GSH content}

After the pre-cultured cells of $C$. tropicalis SHC-03 were transferred into the YPD mediums with different concentration of phenol, the phenol-treated cells and the non-phenol-treated cells were harvested at $3 \mathrm{~h}, 6$ $\mathrm{h}$ and $9 \mathrm{~h}$ for determination of intracellular SOD, GPX, CTT, GLR activity and GSH content. The corresponding values was detected using SOD (Solarbio-BC0170), GPX (Solarbio-BC0090), CTT (SolarbioBC0200), GLR (Solarbio-BC1160), and GSH (Solarbio-BC1175) assay kit purchased from Solarbio (Beijing, China) according to the manufacturer's instructions, respectively.

\section{Cell wall susceptibility analysis}

To understand the structural changes of cell wall induced by phenol, we performed the lyticase-dependent susceptibility analysis [93]. Lyticase (Sigma-Aldrich-L2524), a ß-1,3-glucanase from Arthrobacter luteus, was purchased from Sigma-Aldrich (St. Louis, MO, USA). $10^{7}$ cells, harvested from different mediums with or without phenol, were washed twice with ultrapure water and resuspended in $2.0 \mathrm{ml} \mathrm{PBS} \mathrm{pH} \mathrm{7.0.60}$ $\mu \mathrm{l}$ of a $2 \mathrm{mg} / \mathrm{ml}$ lyticase was mixed into the cell suspensions, the decrease in the $O D_{600}$ of each cell suspension was detected from $0 \mathrm{~h}$ to $4 \mathrm{~h}$.

\section{Abbreviations}

YPD: yeast extract-peptone-dextrose; ROS: reactive oxygen species; ER: endoplasmic reticulum; DCFH-DA: 2' 7'-dichlorofluorescein diacetates; DAPI: diaminophenylindole; qRT-PCR: quantitative real-time polymerase chain reaction; RNA-seq: RNA sequencing; PBS: phosphate buffered solution; FPKM: fragments per kilobase of the transcript per million mapped; SOD: superoxide dismutase; GPX: Glutathione peroxidases; CTT: catalase; GLR: glutathione reductase; GSH: reduced glutathione; MFS: major facilitator superfamily; ABC: adenosine triphosphate (ATP)-binding cassette; dNTP: deoxyribonucleoside triphosphate; UPR: unfolded protein response; ATP: adenosine triphosphate; NAD': nicotinamide adenine dinucleotide; HSP: heat shock protein; MDR: multidrug resistance; MXR: multixenobiotic resistance; OD: optical density; DEGs: differentially expressed genes; Glc, D-glucose; Glc6P, D-glucose-6-phosphate; Fru-6P, D-fructose-6-phosphate; GlcN-6P, D-glucosamine-6-phosphate; GlcNAc6P, N-acetyl-D-glucosamine 6-phosphate; GIcNAc-1P, N-acetyl-alpha-D-glucosamine 1-phosphate; UDPGlcNAc, UDP-N-acetyl-alpha-D-glucosamine; GlcNAc, N-acetyl-D-glucosamine; MHT: Treatments with 1.0 $\mathrm{g} / \mathrm{l}, 2.0 \mathrm{~g} / \mathrm{l}$ and $3.0 \mathrm{~g} / \mathrm{l}$ phenol; LT: Treatments with $0.0 \mathrm{~g} / \mathrm{l}$ and $0.5 \mathrm{~g} / \mathrm{l}$ phenol. 


\section{Declarations}

\section{Acknowledgments}

We are particularly grateful to Z. Lewis Liu, Bioenergy Research Unit, NCAUR-ARS, U.S. Department of Agriculture (Peoria, IL, USA) for providing the mRNA control mix as reference mRNA in the qRT-PCR reactions. We gratefully acknowledge financial support from China Scholarship Council.

\section{Authors' contributions}

MGM, HYW, QL, QC, and XPZ conceived and designed the project. QL, HYW, YYP, ZYZ, XLK, XDH, and XBH performed the experiments. QL, HYW, QJX, XMY, KZ, LKZ, YFG, XL, and XYL performed the data analysis. HYW, QL, YYP, and ZYZ wrote the manuscript. MGM, BDL, EA, and GTA revised the manuscript. All authors read and approved the final manuscript.

\section{Funding}

This work was financially supported by the National Natural Science Foundation of China (No. 31570086), the 2011 Collaborative Innovation Center for Farmland Protection and Agricultural Product Safety in Sichuan Province, and the Talent Introduction Fund of Sichuan Agricultural University (No. 01426100).

\section{Availability of data and materials}

All data generated or analyzed during this study are included in this published article and its additional information files. Transcriptome data is uploaded to NCBI BioProject (Accession Number PRJNA591802). All materials created in this study will be available from the corresponding author on reasonable request.

\section{Ethics approval and consent to participate}

Not applicable.

\section{Consent for publication}

All authors consent to publication. 


\section{Competing interests}

The authors declare that they have no competing interests.

\section{Author details}

${ }^{1}$ Institute of Resources and Geographic Information Technology, College of Resources, Sichuan Agricultural University, Wenjiang, Chengdu 611130, Sichuan, People's Republic of China. ${ }^{2}$ Department of Applied Microbiology, College of Resources, Sichuan Agricultural University, Wenjiang, Chengdu 611130, Sichuan, People's Republic of China. ${ }^{3}$ College of Landscape Architecture, Sichuan Agricultural University, Wenjiang, Chengdu 611130, Sichuan, People's Republic of China. ${ }^{4}$ School of forestry \& life science, Chongqing University of Arts and Sciences, Yongchuan, Chongqing 402160, People's Republic of China. ${ }^{5}$ Department of chemistry and molecular biology, University of Gothenburg, Medicinaregatan 9C, 41390 Göteburg, Sweden.

\section{References}

1. Hu J, Lin Y, Zhang Z, Xiang T, Mei Y, Zhao S, Liang Y, Peng N. High-titer lactic acid production by Lactobacillus pentosus FL0421 from corn stover using fed-batch simultaneous saccharification and fermentation. Bioresour Technol. 2016;214:74-80.

2. Joe MH, Kim JY, Lim S, Kim DH, Bai S, Park H, Lee SG, Han SJ, Choi Jl. Microalgal lipid production using the hydrolysates of rice straw pretreated with gamma irradiation and alkali solution. Biotechnol Biofuels. 2015;8:125.

3.

Reifenrath M, Boles E. Engineering of hydroxymandelate synthases and the aromatic amino acid pathway enables de novo biosynthesis of mandelic and 4-hydroxymandelic acid with Saccharomyces cerevisiae. Metab Eng. 2018;45:246-54.

4. van der Pol EC, Bakker RR, Baets P, Eggink G. By-products resulting from lignocellulose pretreatment and their inhibitory effect on fermentations for (bio)chemicals and fuels. Appl Microbiol Biotechnol. 2014;98(23):9579-93.

5.

Chundawat SP, Beckham GT, Himmel ME, Dale BE. Deconstruction of lignocellulosic biomass to fuels and chemicals. Annu Rev Chem Biomol Eng. 2011;2:121-45. 
6.

Rabemanolontsoa H, Saka S. Various pretreatments of lignocellulosics. Bioresour Technol. 2016;199:8391.

7.

Liu ZL, Blaschek HP. Biomass converion inhibitors and in situ detoxification. In: Vertès AA, Qureshi N, Blaschek HP et al, editors. Biomass to Biofuels: Strategies for Global Industries. West Sussex: John Wiley and Sons; 2010. pp. 233-59.

8.

Liu ZL. Molecular mechanisms of yeast tolerance and in situ detoxification of lignocellulose hydrolysates. Appl Microbiol Biotechnol. 2011;90(3):809-25.

9.

Heipieper HJ, Keweloh H, Rehm HJ. Influence of phenols on growth and membrane permeability of free and immobilized Escherichia coli. Appl Environ Microbiol. 1991;57(4):1213-7.

10.

Keweloh H, Heipieper H-J, Rehm H-J. Protection of bacteria against toxicity of phenol by immobilization in calcium alginate. Appl Microbiol Biotechnol. 1989;31(4):383-9.

11.

Keweloh H, Weyrauch G, Rehm H-J. Phenol-induced membrane changes in free and immobilized Escherichia coli. Appl Microbiol Biotechnol. 1990;33(1):66-71.

12.

Larsson S, Reimann A, Nilvebrant NO, Jönsson LJ, Davison BH, Finkelstein M. Comparison of different methods for the detoxification of lignocellulose hydrolyzates of spruce. Appl Microbiol Biotechnol. 1999;77(1-3):91-103.

13.

Zhou L, Cheng D, Wang L, Gao J, Zhao Q, Wei W, Sun Y. Comparative transcriptomic analysis reveals phenol tolerance mechanism of evolved Chlorella strain. Bioresour Technol. 2017;227:266-72. 14.

Larsson S, Palmqvist E, Hahn-Hägerdal B, Tengborg C, Stenberg K, Zacchi G, Nilvebrant N-O. The generation of fermentation inhibitors during dilute acid hydrolysis of softwood. Enzyme Microb Tech. $1999 ; 24(3-4): 151-9$.

15.

Jonsson LJ, Alriksson B, Nilvebrant NO. Bioconversion of lignocellulose: inhibitors and detoxification. Biotechnol Biofuels. 2013;6(1):16.

16.

Palmqvist E, Hahnhägerdal B. Fermentation of lignocellulosic hydrolysates. II: inhibitors and mechanisms of inhibition. Bioresource Technol. 2000;74(1):25-33.

17.

Wang X, Li BZ, Ding MZ, Zhang WW, Yuan YJ. Metabolomic analysis reveals key metabolites related to the rapid adaptation of Saccharomyce cerevisiae to multiple inhibitors of furfural, acetic acid, and phenol. OMICS. 2013;17(3):150-9. 
18.

Parawira W, Tekere M. Biotechnological strategies to overcome inhibitors in lignocellulose hydrolysates for ethanol production: review. Crit Rev Biotechnol. 2011;31(1):20-31.

19.

Peng X, Shindo K, Kanoh K, Inomata Y, Choi SK, Misawa N. Characterization of Sphingomonas aldehyde dehydrogenase catalyzing the conversion of various aromatic aldehydes to their carboxylic acids. Appl Microbiol Biotechnol. 2005;69(2):141-50.

20.

Liu ZL, Moon J, Andersh BJ, Slininger PJ, Weber S. Multiple gene-mediated NAD(P)H-dependent aldehyde reduction is a mechanism of in situ detoxification of furfural and 5-hydroxymethylfurfural by Saccharomyces cerevisiae. Appl Microbiol Biotechnol. 2008;81(4):743-53.

21.

Endo A, Nakamura T, Ando A, Tokuyasu K, Shima J. Genome-wide screening of the genes required for tolerance to vanillin, which is a potential inhibitor of bioethanol fermentation, in Saccharomyces cerevisiae. Biotechnol Biofuels. 2008;1(1):3.

22.

Gu H, Zhang J, Bao J. High tolerance and physiological mechanism of Zymomonas mobilis to phenolic inhibitors in ethanol fermentation of corncob residue. Biotechnol Bioeng. 2015;112(9):1770-82. 23.

Yi X, Gu H, Gao Q, Liu ZL, Bao J. Transcriptome analysis of Zymomonas mobilis ZM4 reveals mechanisms of tolerance and detoxification of phenolic aldehyde inhibitors from lignocellulose pretreatment. Biotechnol Biofuels. 2015;8:153.

24.

Yoneda A, Henson WR, Goldner NK, Park KJ, Forsberg KJ, Kim SJ, Pesesky MW, Foston M, Dantas G, Moon TS. Comparative transcriptomics elucidates adaptive phenol tolerance and utilization in lipidaccumulating Rhodococcus opacus PD630. Nucleic Acids Res. 2016;44(5):2240-54.

25.

Kawachi H, Shimizu K, Atomi H, Sanuki Si, Ueda M, Tanaka A. Gene analysis of an NADP-linked isocitrate dehydrogenase localized in peroxisomes of the $\mathrm{n}$-alkane-assimilating yeast Candida tropicalis. Eur $\mathrm{J}$ Biochem. 1997;250(1):205-11.

26.

Kurihara T, Ueda M, Okada H, Kamasawa N, Naito N, Osumi M, Tanaka A. Beta-oxidation of butyrate, the short-chain-length fatty acid, occurs in peroxisomes in the yeast Candida tropicalis. J Biochem. $1992 ; 111(6): 783-7$.

27.

Sampaio JP. Utilization of low molecular weight aromatic compounds by heterobasidiomycetous yeasts: taxonomic implications. Can J Microbiol. 1999;45(6):491-512.

28.

Horitsu H, Yahashi Y, Takamizawa K, Kawai K, Suzuki T, Watanabe N. Production of xylitol from D-xylose by Candida tropicalis: optimization of production rate. Biotechnol Bioeng. 1992;40(9):1085-91. 
29.

García MJ, Ríos G, Ali R, Bellés JM, Serrano R. Comparative physiology of salt tolerance in Candida tropicalis and Saccharomyces cerevisiae. Microbiology. 1997;143(Pt 4):1125-31.

30 .

Adav SS, Chen MY, Lee DJ, Ren NQ. Degradation of phenol by aerobic granules and isolated yeast Candida tropicalis. Biotechnol Bioeng. 2007;96(5):844-52.

31.

Wang S, Li H, Fan X, Zhang J, Tang P, Yuan Q. Metabolic responses in Candida tropicalis to complex inhibitors during xylitol bioconversion. Fungal Genet Biol. 2015;82:1-8.

32.

Butler G, Rasmussen MD, Lin MF, Santos MA, Sakthikumar S, Munro CA, Rheinbay E, Grabherr M, Forche A, Reedy JL, Agrafioti I, Arnaud MB, Bates S, Brown AJ, Brunke S, Costanzo MC, Fitzpatrick DA, de Groot PW, Harris D, Hoyer LL, Hube B, Klis FM, Kodira C, Lennard N, Logue ME, Martin R, Neiman AM, Nikolaou E, Quail MA, Quinn J, Santos MC, Schmitzberger FF, Sherlock G, Shah P, Silverstein KA, Skrzypek MS, Soll D, Staggs R, Stansfield I, Stumpf MP, Sudbery PE, Srikantha T, Zeng Q, Berman J, Berriman M, Heitman J, Gow NA, Lorenz MC, Birren BW, Kellis M, Cuomo CA. Evolution of pathogenicity and sexual reproduction in eight Candida genomes. Nature. 2009;459(7247):657-62.

33.

Krug M, Ziegler H, Straube G. Degradation of phenolic compounds by the yeast Candida tropicalis HP 15. I. Physiology of growth and substrate utilization. J Basic Microbiol. 1985;25(2):103-10.

34.

Jiang Y, Wen J, Li H, Yang S, Hu Z. The biodegradation of phenol at high initial concentration by the yeast Candida tropicalis. Biochem Eng J. 2005;24(3):243-7.

35 .

Klaunig JE, Wang Z, Pu X, Zhou S. Oxidative stress and oxidative damage in chemical carcinogenesis. Toxicol Appl Pharmacol. 2011;254(2):86-99.

36.

Hossain MZ, Teixeira da Silva JA. M. F. Differential roles of glutathione S-transferase in oxidative stress modulation. In: Teixeira da Silva JA, editor. Floriculture, ornamental and plant biotechnology. Advances and topical issueses. London: Global Science Books Ltd; 2006. pp. 108-16.

37.

Perrone GG, Tan SX, Dawes IW. Reactive oxygen species and yeast apoptosis. Biochim Biophys Acta. 2008;1783(7):1354-68.

38.

Rowe LA, Degtyareva N, Doetsch PW. DNA damage-induced reactive oxygen species (ROS) stress response in Saccharomyces cerevisiae. Free Radic Biol Med. 2008;45(8):1167-77.

39.

Gourlay CW, Ayscough KR. Identification of an upstream regulatory pathway controlling actin-mediated apoptosis in yeast. J Cell Sci. 2005;118(Pt 10):2119-32.

40 . 
Gill SS, Anjum NA, Hasanuzzaman M, Gill R, Trivedi DK, Ahmad I, Pereira E, Tuteja N. Glutathione and glutathione reductase: a boon in disguise for plant abiotic stress defense operations. Plant Physiol Biochem. 2013;70:204-12.

41.

Madeo F, Frohlich E, Ligr M, Grey M, Sigrist SJ, Wolf DH, Frohlich KU. Oxygen stress: a regulator of apoptosis in yeast. J Cell Biol. 1999;145(4):757-67.

42.

Yao R, Zhang Z, An X, Bucci B, Perlstein DL, Stubbe J, Huang M. Subcellular localization of yeast ribonucleotide reductase regulated by the DNA replication and damage checkpoint pathways. Proc Natl Acad Sci U S A. 2003;100(11):6628-33.

43.

Mayer ML, Gygi SP, Aebersold R, Hieter P. Identification of RFC(Ctf18p, Ctf8p, Dcc1p) an alternative RFC complex required for sister chromatid cohesion in S. cerevisiae. Mol Cell. 2001;7(5):959-70.

44.

Senft D, Ronai Z. UPR, autophagy, and mitochondria crosstalk underlies the ER stress response. Trends Biochem Sci. 2015;40(3):141-8.

45.

Lanneau D, Wettstein G, Bonniaud P, Garrido C. Heat shock proteins: cell protection through protein triage. Sci World J. 2010;10:1543-52.

46.

Obeng EA, Carlson LM, Gutman DM, Harrington WJ Jr, Lee KP. LH. B. Proteasome inhibitors induce a terminal unfolded protein response in multiple myeloma cells. Blood. 2006;107(12):4907-16.

47.

Doong H, Rizzo K, Fang S, Kulpa V, Weissman AM. EC. K. CAIR-1/BAG-3 abrogates heat shock protein-70 chaperone complex-mediated protein degradation: accumulation of poly-ubiquitinated Hsp90 client proteins. J Biol Chem. 2003;278(31):28490-500.

48.

Suzuki K, Ohsumi Y. Molecular machinery of autophagosome formation in yeast, Saccharomyces cerevisiae. FEBS Lett. 2007;581(11):2156-61.

49.

Oku M, Nishimura T, Hattori T, Ano Y, Yamashita S-i, Sakai Y. Role of vac8 in formation of the vacuolar sequestering membrane during micropexophagy. Autophagy. 2006;2(4):272-9.

50 .

Kurosawa K, Laser J, Sinskey AJ. Tolerance and adaptive evolution of triacylglycerol-producing Rhodococcus opacus to lignocellulose-derived inhibitors. Biotechnol Biofuels. 2015;8:76.

51.

Teixeira MC, Monteiro PT, Guerreiro JF, Goncalves JP, Mira NP, dos Santos SC, Cabrito TR, Palma M, Costa C, Francisco AP, Madeira SC, Oliveira AL, Freitas AT, Sa-Correia I. The YEASTRACT database: an upgraded information system for the analysis of gene and genomic transcription regulation in Saccharomyces cerevisiae. Nucleic Acids Res. 2014;42(Database issue):D161-6. 
52.

Dos Santos SC, Teixeira MC, Dias PJ, Sa-Correia I. MFS transporters required for multidrug/multixenobiotic (MD/MX) resistance in the model yeast: understanding their physiological function through post-genomic approaches. Front Physiol. 2014;5:180.

53.

Higgins CF. Multiple molecular mechanisms for multidrug resistance transporters. Nature. 2007;446(7137):749-57.

54.

Sa-Correia I, dos Santos SC, Teixeira MC, Cabrito TR, Mira NP. Drug:H + antiporters in chemical stress response in yeast. Trends Microbiol. 2009;17(1):22-31.

55.

Varma RJ, Gaikwad BG. Biodegradation and phenol tolerance by recycled cells of Candida tropicalis NCIM 3556. Int Biodeter Biodegr. 2009;63(4):539-42.

56 .

Long Y, Yang S, Xie Z, Cheng L. Identification and characterization of phenol hydroxylase from phenoldegrading Candida tropicalis strain JH8. Can J Microbiol. 2014;60(9):585-91.

57.

Wang L, Lin Y, Yang L, Yu P, Xie Z, Luo Y. Candida tropicalis: characterization of a strain capable of degrading high concentrations of phenol. Biotechnol Lett. 2011;33(5):943-6.

58.

Masutomi K, Possemato R, Wong JM, Currier JL, Tothova Z, Manola JB, Ganesan S, Lansdorp PM, Collins $\mathrm{K}$, Hahn WC. The telomerase reverse transcriptase regulates chromatin state and DNA damage responses. Proc Natl Acad Sci U S A. 2005;102(23):8222-7.

59.

Lima CF, Fernandes-Ferreira M, Pereira-Wilson C. Phenolic compounds protect HepG2 cells from oxidative damage: relevance of glutathione levels. Life Sci. 2006;79(21):2056-68.

60.

Hartl FU, Hayer-Hartl M. Molecular chaperones in the cytosol from nascent chain to folded protein. Science. 2002;295(5561):1852-8.

61.

Walter S, Buchner J. Molecular chaperones-cellular machines for protein folding. Angew Chem Int Ed Engl. 2002;41(7):1098-113.

62.

Demand J, Alberti S, Patterson C, Hohfeld J. Cooperation of a ubiquitin domain protein and an E3 ubiquitin ligase during chaperone/proteasome coupling. Curr Biol. 2001;11(20):1569-77. 63.

Wang CW, Klionsky DJ. The molecular mechanism of autophagy. Mol Med. 2003;9(3-4):65-76. 64.

Baba M, Takeshige K, Baba N, Ohsumi Y. Ultrastructural analysis of the autophagic process in yeast: detection of autophagosomes and their characterization. J Cell Biol. 1994;124(6):903-13. 
65.

Schneiter R, Guerra C, Lampl M, Tatzer V, Zellnig G, Klein H, Kohlwein S. A novel cold-sensitive allele of the rate-limiting enzyme of fatty acid synthesis, acetyl coenzyme A carboxylase, affects the morphology of the yeast vacuole through acylation of Vac8p. Mol Cell Biol. 2000;20(9):2984-95.

66.

Yang J, Ding MZ, Li BZ, Liu ZL, Wang X, Yuan YJ. Integrated phospholipidomics and transcriptomics analysis of Saccharomyces cerevisiae with enhanced tolerance to a mixture of acetic acid, furfural, and phenol. OMICS. 2012;16(7-8):374-86.

67.

Bulik DA, Olczak M, Lucero HA, Osmond BC, Robbins PW, Specht CA. Chitin synthesis in Saccharomyces cerevisiae in response to supplementation of growth medium with glucosamine and cell wall stress. Eukaryot Cell. 2003;2(5):886-900.

68.

Ruiz-Herrera J, Martínez Al, Sentandreu R. Determination of the stability of protein pools from the cell wall of fungi. Res Microbiol. 2002;153(6):373-8.

69.

Deshpande MV, O'Donnell R, Gooday GW. Regulation of chitin synthase activity in the dimorphic fungus Benjaminiella poitrasii by external osmotic pressure. FEMS Microbiol Lett. 1997;152(2):327-32. 70.

Aguilar-Uscanga B, Francois JM. A study of the yeast cell wall composition and structure in response to growth conditions and mode of cultivation. Lett Appl Microbiol. 2003;37(3):268-74.

71.

Herman PK. Stationary phase in yeast. Curr Opin Microbiol. 2002;5(6):602-7.

72.

Gulshan K, Moye-Rowley WS. Multidrug resistance in fungi. Eukaryot Cell. 2007;6(11):1933-42. 73.

Nikaido H. Multidrug resistance in bacteria. Annu Rev Biochem. 2009;78:119-46. 74.

Ma M, Liu ZL. Comparative transcriptome profiling analyses during the lag phase uncover YAP. PDR1, PDR3, RPN4, and HSF1 as key regulatory genes in genomic adaptation to the lignocellulose derived inhibitor HMF for Saccharomyces cerevisiae. BMC Genom. 2010;1:11:660.

75.

Lin CP, Kim C, Smith SO, AM N. A highly redundant gene network controls assembly of the outer spore wall in S. cerevisiae. PLoS Genet. 2013;9(8):e1003700.

76.

Nunes PA, Tenreiro S, Sa-Correia I. Resistance and adaptation to quinidine in Saccharomyces cerevisiae: role of QDR1. (YIL120w), encoding a plasma membrane transporter of the major facilitator superfamily required for multidrug resistance. Antimicrob Agents Chemother. 2001;45(5):1528-34.

77. 
Baker LG, Specht CA, Donlin MJ, Lodge JK. Chitosan, the deacetylated form of chitin, is necessary for cell wall integrity in Cryptococcus neoformans. Eukaryot Cell. 2007;6(5):855-67.

78.

Neiman AM. Sporulation in the budding yeast Saccharomyces cerevisiae. Genetics. 2011;189(3):737-65. 79 .

Kupiec M, Byers B, Esposito R. Meiosis and sporulation in Saccharomyces cerevisiae. In: Pringle J, Broach J, Jones E, editors. The Molecular and Cellular Biology of the Yeast Saccharomyces cerevisiae. NY: Cold Spring Harbor; 1997. pp. 889-1036.

80.

Briza P, Breitenbach M, Ellinger A, Segall J. Isolation of two developmentally regulated genes involved in spore wall maturation in Saccharomyces cerevisiae. Genes Dev. 1990;4(10):1775-89.

81.

Pammer M, Briza P, Ellinger A, Schuster T, Stucka R, Feldmanns H, Breitenbach M. (CSD2, CAL1), a cell cycle-regulated yeast gene required for synthesis of chitin in cell walls and chitosan in spore walls. Yeast. 1992;DIT101(12):1089-99. 8(.

82.

Anders S, Huber W. Differential expression analysis for sequence count data. Genome Biol. 2010;11(10):R106.

83.

Liu ZL, Slininger PJ. Universal external RNA controls for microbial gene expression analysis using microarray and qRT-PCR. J Microbiol Methods. 2007;68(3):486-96.

84.

Florea L, Song L, Salzberg SL. Thousands of exon skipping events differentiate among splicing patterns in sixteen human tissues. F1000Res. 2013;2:188.

85.

Tatusov RL, Galperin MY, Natale DA, Koonin EV. The COG database a tool for genome-scale analysis of protein functions and evolution. Nucleic Acids Res. 2000;28(1):33-6.

86.

Ashburner M, Ball C, Blake J, Botstein D, Butler H, Cherry J, Davis A, Dolinski K, Dwight S, Eppig J, Harris M, Hill D, Issel-Tarver L, A K, Lewis S, Matese J, Richardson J, Ringwald M, Rubin G, Sherlock G. Gene ontology tool for the unification of biology. Nat Genet. 2000;25(1):25-9.

87.

Kanehisa M, Goto S, Kawashima S, Okuno Y, Hattori M. The KEGG resource for deciphering the genome. Nucleic Acids Res. 2004;32(Database issue):D277-80.

88.

Koonin EV, Fedorova ND, Jackson JD, Jacobs AR, Krylov DM, Makarova KS, Mazumder R, Mekhedov SL, Nikolskaya AN, Rao BS, Rogozin IB, Smirnov S, Sorokin AV, Sverdlov AV, Vasudevan S, Wolf YI, Yin JJ, Natale DA. A comprehensive evolutionary classification of proteins encoded in complete eukaryotic genomes. Genome Biol. 2004;5(2):R7.

89. 
The UniProt C. UniProt: the universal protein knowledgebase. Nucleic Acids Res. 2017;45(D1):D158-69. 90.

Finn RD, Bateman A, Clements J, Coggill P, Eberhardt RY, Eddy SR, Heger A, Hetherington K, Holm L, Mistry J, Sonnhammer EL, Tate J, Punta M. Pfam: the protein families database. Nucleic Acids Res. 2014;42(Database issue):D222-30.

91.

Deng YY, Li JQ, Wu SF, Zhu Y, Chen YW, He FC. Integrated nr database in protein annotation system and its localization. Comput Eng. 2006;32(5):71-3.

92.

Mao X, Cai T, Olyarchuk JG, Wei L. Automated genome annotation and pathway identification using the KEGG Orthology (KO) as a controlled vocabulary. Bioinformatics. 2005;21(19):3787-93.

93.

Teixeira MC, Raposo LR, Mira NP, Lourenco AB, Sa-Correia I. Genome-wide identification of Saccharomyces cerevisiae genes required for maximal tolerance to ethanol. Appl Environ Microbiol. 2009;75(18):5761-72.

\section{Figures}




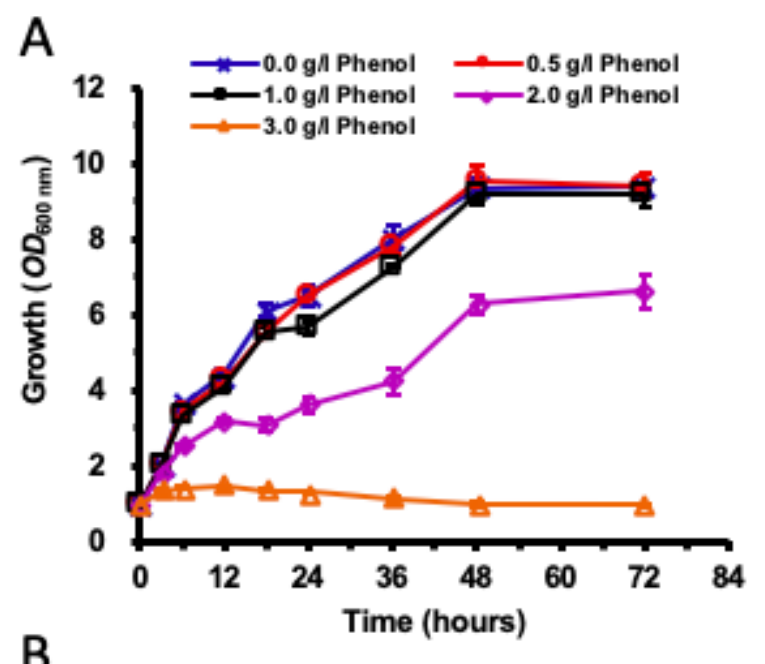

B

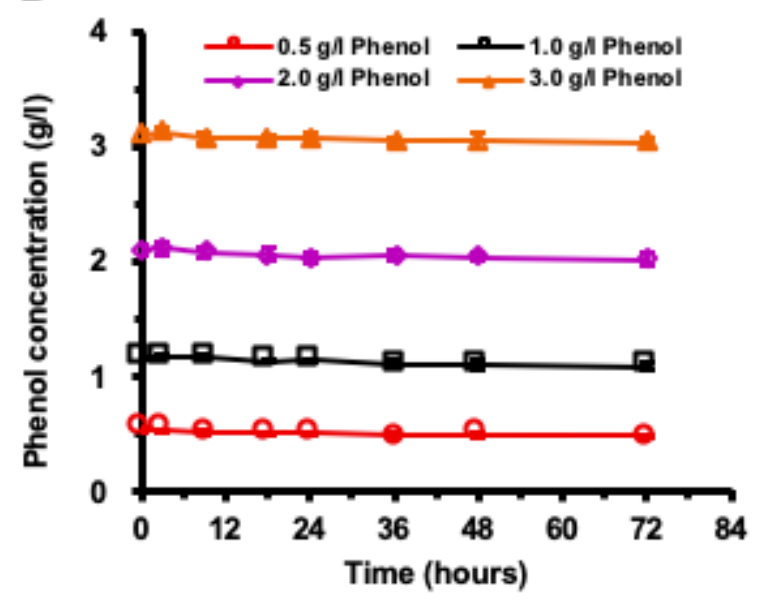

Figure 1

Inhibition of C. tropicalis SHC-03 cell growth by different concentrations of phenol. (A) Cell growth as measured by reading absorbance at $600 \mathrm{~nm}$ (OD600). (B) Phenol consumption. 

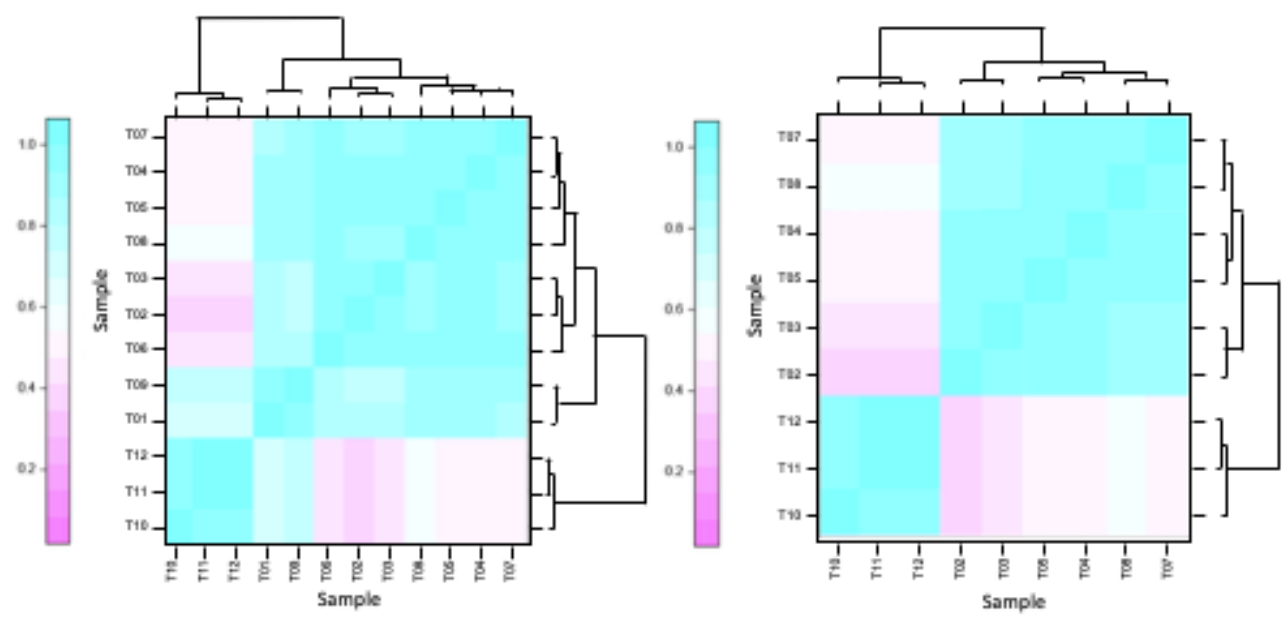

C

D

$\mathrm{E}$
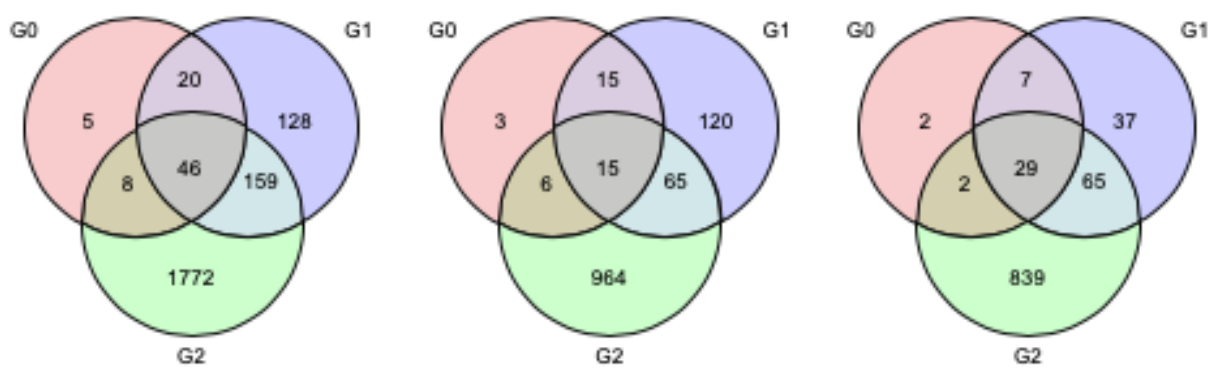

$\mathrm{F}$

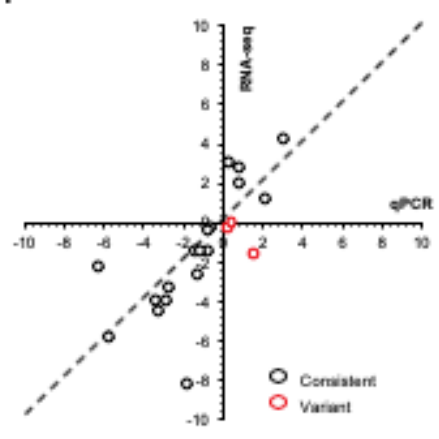

Figure 2

Transcriptome response to phenol after treatment for $3 \mathrm{~h}$ and comparison of expression levels of the selected genes as determined by RNA-seq and qRT-PCR. (A) Hierarchical cluster analysis of all replications. Replications of each phenol treatment group analyzed for RNA transcription are labeled as follows: $0.0 \mathrm{~g} / \mathrm{l}$ phenol (T01, T02, T03); $0.5 \mathrm{~g} / \mathrm{l}$ phenol (T04, T05, T06); $1.0 \mathrm{~g} / \mathrm{l}$ phenol (T07, T08, T09); 2.0 $\mathrm{g} / \mathrm{l}$ phenol $(\mathrm{T} 10, \mathrm{~T} 11, \mathrm{~T} 12)$. Given the log2(fold change), expression levels of genes were clustered. (B) Hierarchical cluster analysis of the replications that did not include samples T01, T05, and T09. After T01, T05, and T09 were eliminated as outliers, three Venn diagrams were created based on differentially expressed genes in response to $0.5 \mathrm{~g} / \mathrm{l}$ phenol (G0), $1.0 \mathrm{~g} / \mathrm{l}$ phenol (G1), and $2.0 \mathrm{~g} / \mathrm{l}$ phenol (G2), compared with the control group. (C) Differential expression of all genes. (D) Differential expression of up-regulated genes. (E) Differential expression of down-regulated genes. (F) Comparison of expression 
levels of the selected genes between the RNA-seq and qRT-PCR. The gene expression ratios of RNA-seq and qRT-PCR for 21 genes in response to $1.0 \mathrm{~g} / \mathrm{l}$ phenol were calculated according to the values of log2(fold change) (treatment/control). The 21 selected genes included CTRG_00166, CTRG_00173, CTRG_00423, CTRG_00627, CTRG_00770, CTRG_01068, CTRG_01142, CTRG_01327, CTRG_01443, CTRG_01732, CTRG_01733, CTRG_01777, CTRG_02090, CTRG_02168, CTRG_02702, CTRG_03102, CTRG_03235, CTRG_03453, CTRG_03911, CTRG_03917, and CTRG_03930. The primers for RT-PCR of these selected genes are listed in Additional File 7.

A
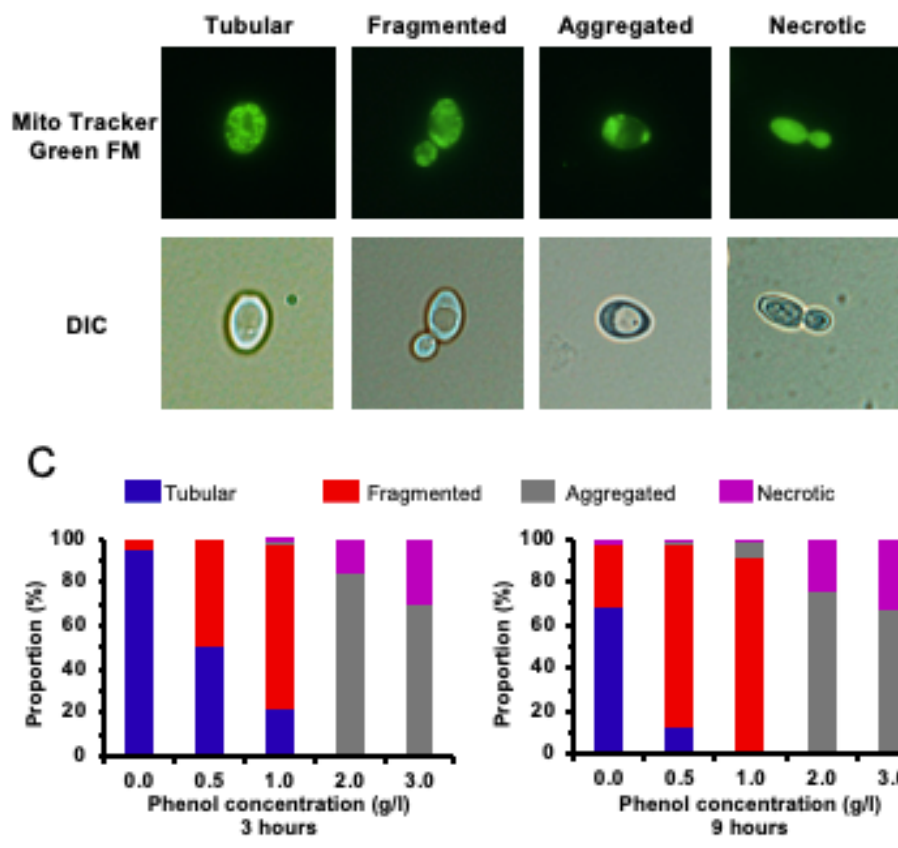

D
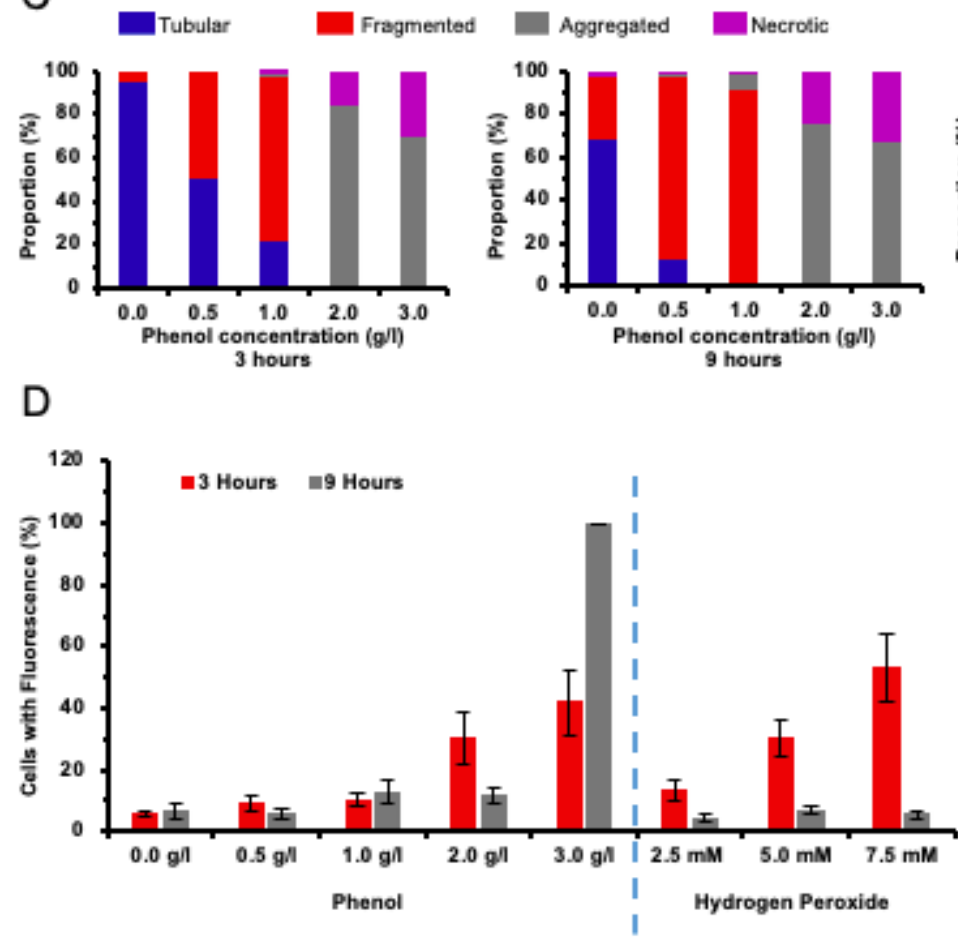

B
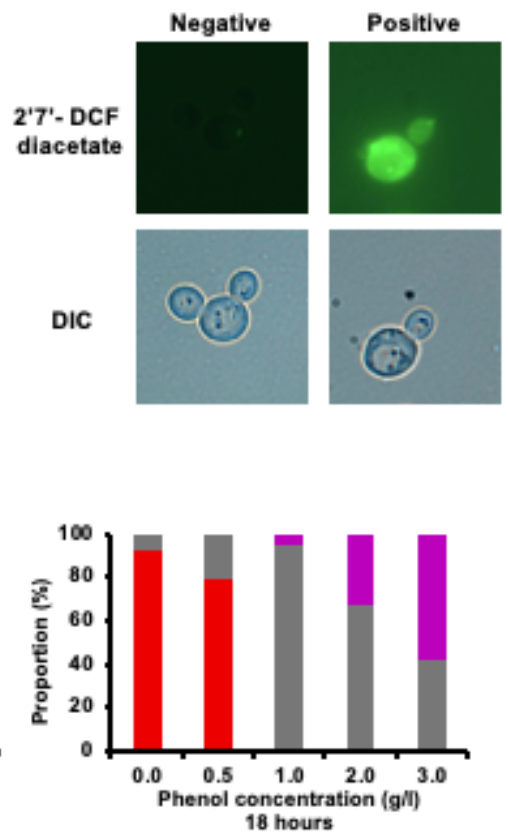

\section{Figure 3}

Mitochondrial membrane damage and accumulation of reactive oxygen species (ROS) caused by phenol. Representative images of cells stained with the mitochondria-specific dye Mito TrackerTM Green FM and ROS indicator dye 2' 7'-dichlorofluorescein diacetate (DCFH-DA) are shown in the top column, and images taken using a differential interference contrast (DIC) lens are shown in the bottom column. (A) Morphological structure analysis of mitochondria. (B) Accumulation analysis of ROS. (C) Percentage of cells at each concentration of phenol that displayed tubular, fragmented, and aggregated mitochondria, 
as well as necrotic, at $3 \mathrm{~h}, 9 \mathrm{~h}$, and $18 \mathrm{~h}$. (D) Percentage of cells at each concentration of phenol and hydrogen peroxide that stained positive for ROS by DCFH-DA at $3 \mathrm{~h}$ and $9 \mathrm{~h}$, with cultures in medium containing $2.5 \mathrm{mM}, 5.0 \mathrm{mM}$, and $7.5 \mathrm{mM}$ hydrogen peroxide as positive controls for ROS. The data represent averages of three experiments. At least 100 cells were examined on each bright-field image.

A
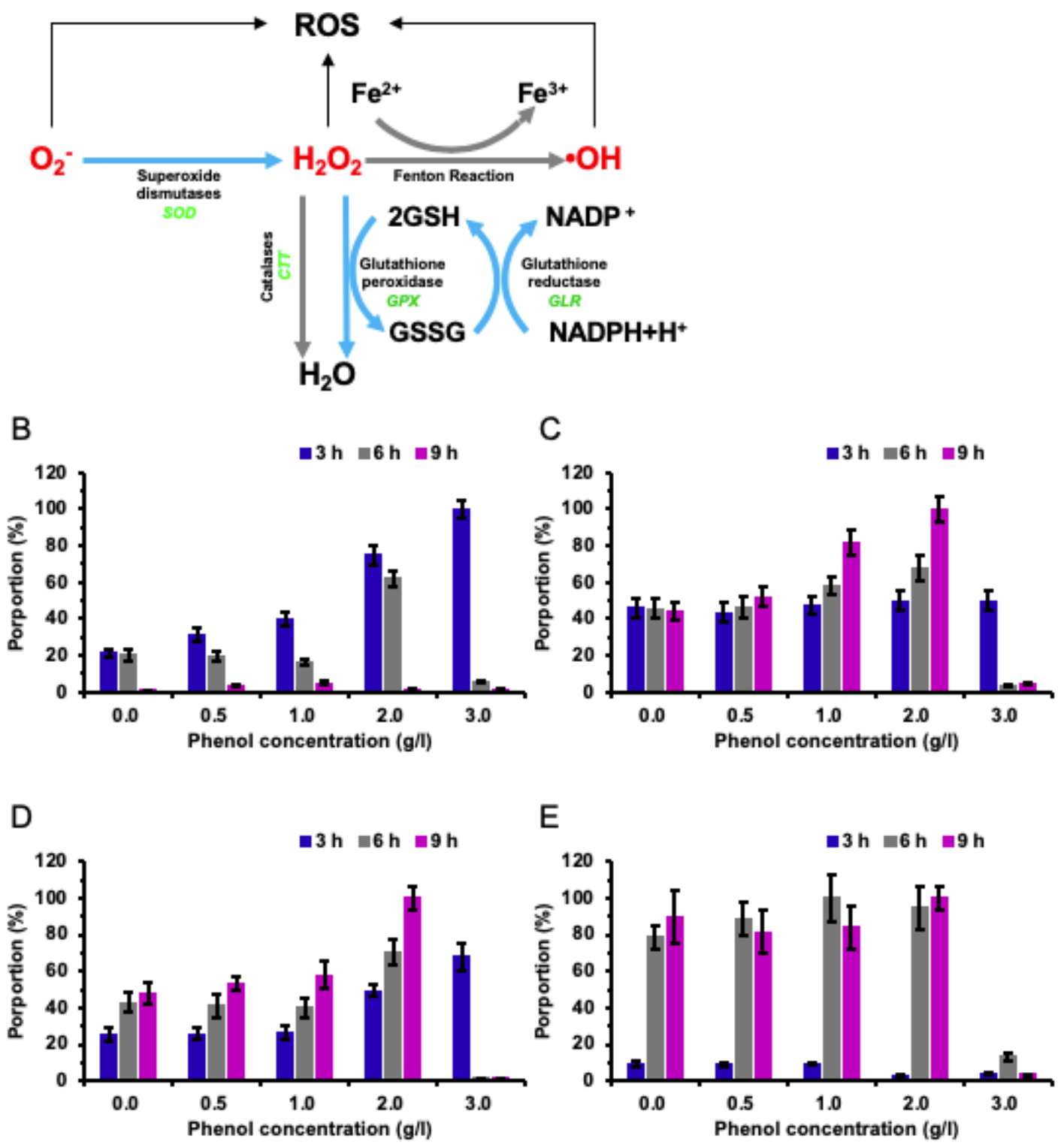

Figure 4

Pathway for reactive oxygen species (ROS) scavenging in C. tropicalis SHC-03 and the change in activity of ROS-related enzymes after treatment with phenol. (A) The pathway shows the scavenging of reactive oxygen species (ROS) catalyzed by enzymatic antioxidant defense systems containing SOD, GPX, CTT, GLR, and GSH. (B-E) Activities of (B) SOD, (C) GPX, (D) GLR, and (E) GSH after treatments with 0.0-3.0 g/I phenol for $3 \mathrm{~h}, 6 \mathrm{~h}$, and $9 \mathrm{~h}$. 
A

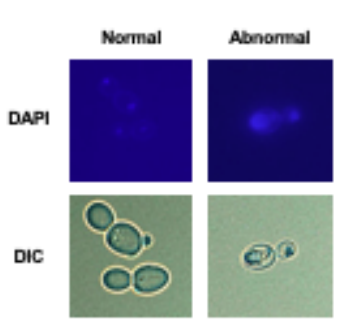

B

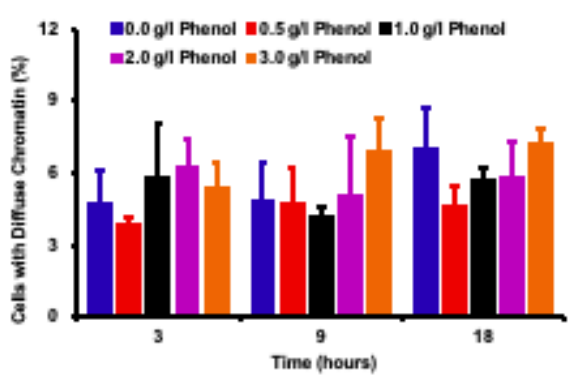

C
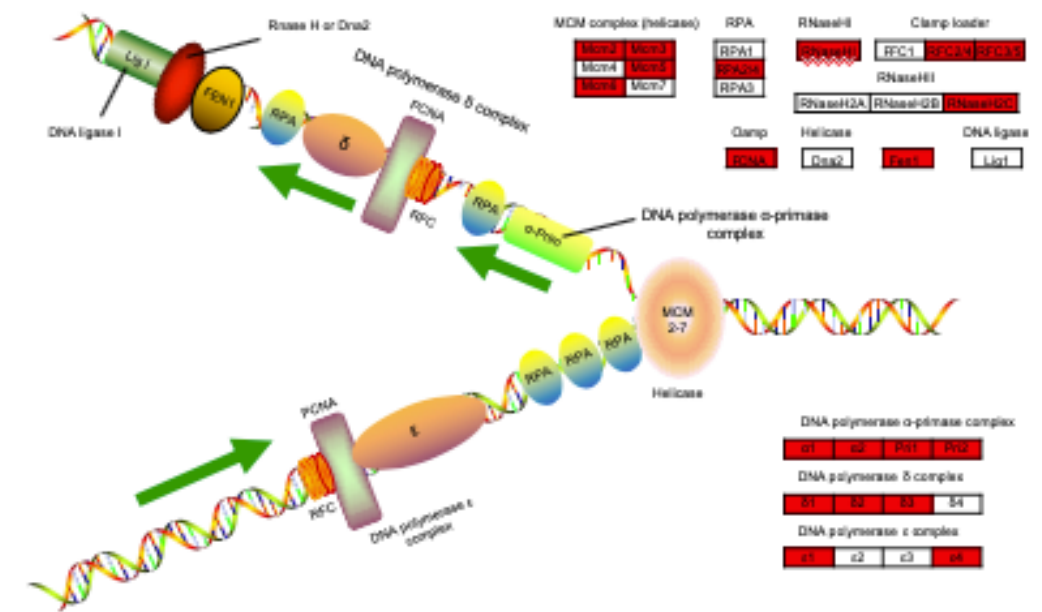

D

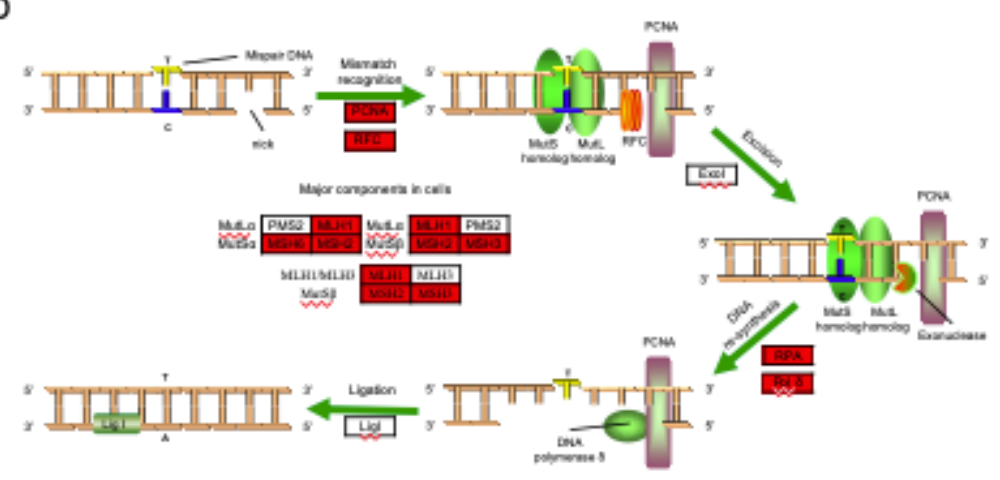

Figure 5

Morphological change in nuclear chromatin caused by phenol and the protection of nuclear DNA. (A) Representative images of cells stained with the DNA specific dye diaminophenylindole (DAPI) are shown in the top column, and images taken by a differential interference contrast (DIC) lens are shown in the bottom column. (B) Percentage of cells containing abnormal chromatin in the presence of each concentration of phenol at $3 \mathrm{~h}, 9 \mathrm{~h}$, and $18 \mathrm{~h}$. Data represent averages of three experiments. At least 100 cells were examined on each bright-field image. (C, D) DNA replication (C) and DNA mismatch repair (D) pathways. Red genes were up-regulated by twofold in the presence of $2.0 \mathrm{~g} / \mathrm{l}$ phenol and listed in Additional File 3. 

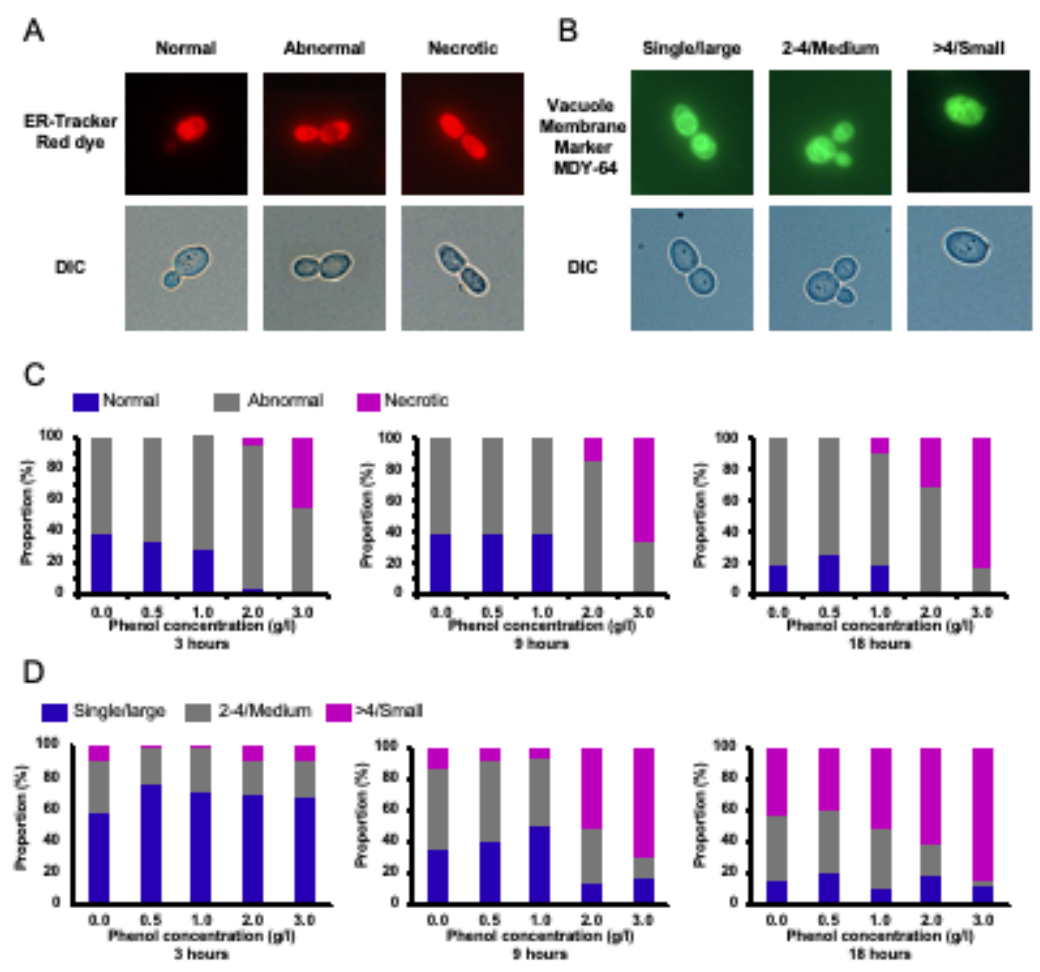

Figure 6

Endoplasmic reticulum (ER) and vacuole damage caused by phenol. Representative images of cells stained with the ER-specific dye ER-TrackerTM Red and vacuole-targeted dye Yeast Vacuole Membrane Marker MDY-64 are shown in the top column, and images taken using a differential interference contrast (DIC) lens are shown in the bottom column. (A) Morphological structure analysis of the ER. (B) Morphological structure analysis of the vacuole. (C) Percentage of cells at each concentration of phenol that displayed normal, abnormal, and necrotic ER at $3 \mathrm{~h}, 9 \mathrm{~h}$, and $18 \mathrm{~h}$. (D) Percentage of cells at each concentration of phenol that contained large, medium, and small vacuoles at $3 \mathrm{~h}, 9 \mathrm{~h}$, and $18 \mathrm{~h}$. Data represent averages of three experiments. At least 100 cells were examined on each bright-field image. 


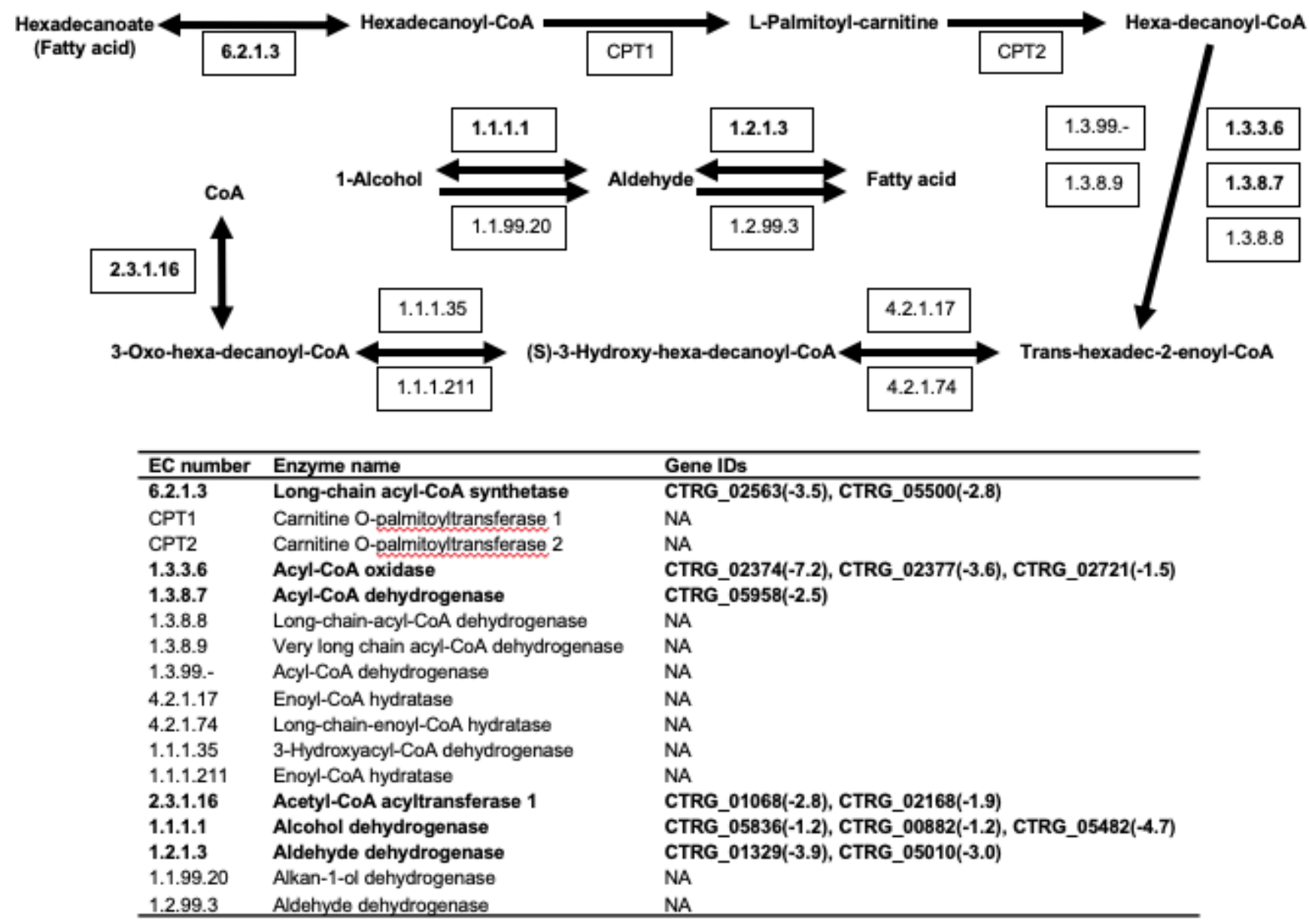

Figure 7

Fatty acid degradation pathway in C. tropicalis $\mathrm{SHC}-03$. Known enzymatic reactions in C. tropicalis are shown in bold font. Expression levels of genes with values of log2(fold change) in response to $2.0 \mathrm{~g} / \mathrm{l}$ phenol, compared with the control group, are shown. NA=none annotated. 
A

$6+2024$

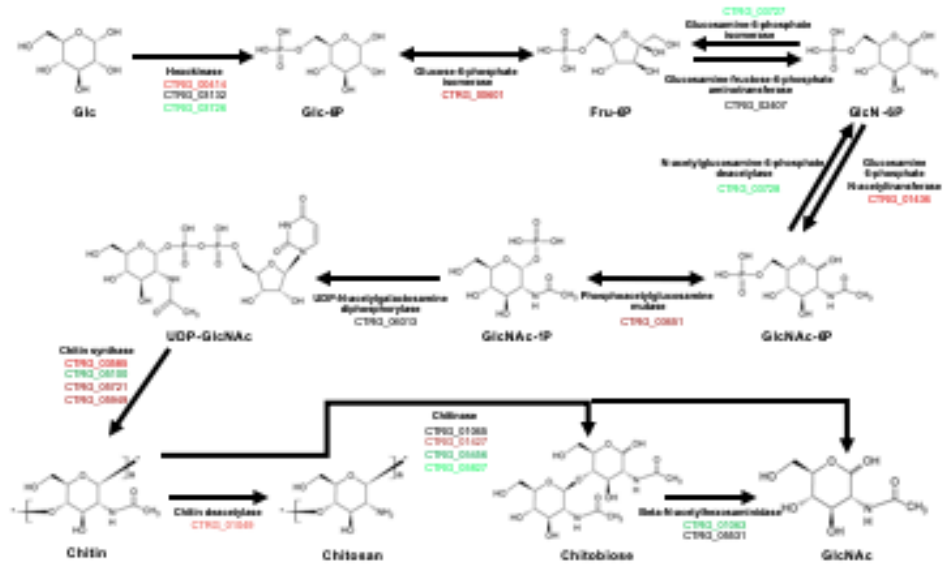

B

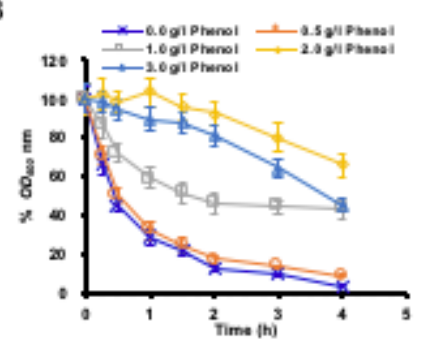

C

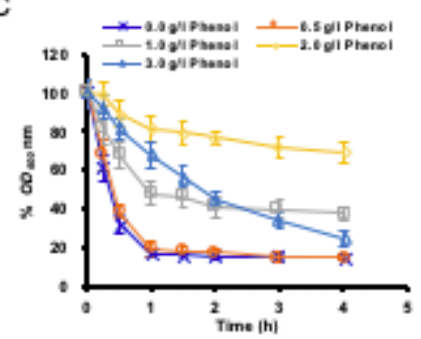

D

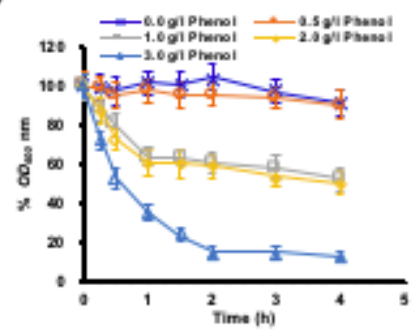

Figure 8

Synthesis and degradation of chitin in cells exposed to $2.0 \mathrm{~g} / \mathrm{l}$ phenol and susceptibility to lyticase of cells treated with 0.0-3.0 g/l phenol for $3 \mathrm{~h}, 9 \mathrm{~h}$, and $18 \mathrm{~h}$. (A) Pathway showing genes involved in chitin synthesis and degradation. The color codes red, black, and green represent up-regulated, normal, and down-regulated expression, respectively, in the presence of $2.0 \mathrm{~g} / \mathrm{l}$ phenol. Glc, D-Glucose; Glc-6P, DGlucose-6-phosphate; Fru-6P, D-Fructose-6-phosphate; GlcN-6P, D-Glucosamine-6-phosphate; GIcNAc-6P, N-Acetyl-D-glucosamine 6-phosphate; GlcNAc-1P, N-Acetyl-alpha-D-glucosamine 1-phosphate; UDPGlcNAc, UDP-N-acetyl-alpha-D-glucosamine; GlcNAc, N-Acetyl-D-glucosamine. The expression levels of the genes (log2 transformed) are listed in Additional File 5. The mean values of relative optical density are presented with vertical error bars, each representing a single standard deviation $(n=3)$. $(B, C, D)$ Change in cell density after treatment in PBS containing lyticase from $0 \mathrm{~h}$ to $4 \mathrm{~h}$ after incubation. Cells treated for (B) $3 \mathrm{~h},(C) 9 \mathrm{~h}$, and (D) $18 \mathrm{~h}$ under phenol stress or no phenol stress. The mean values of relative optical density are presented with vertical error bars, each representing a single standard deviation $(n=3)$. 


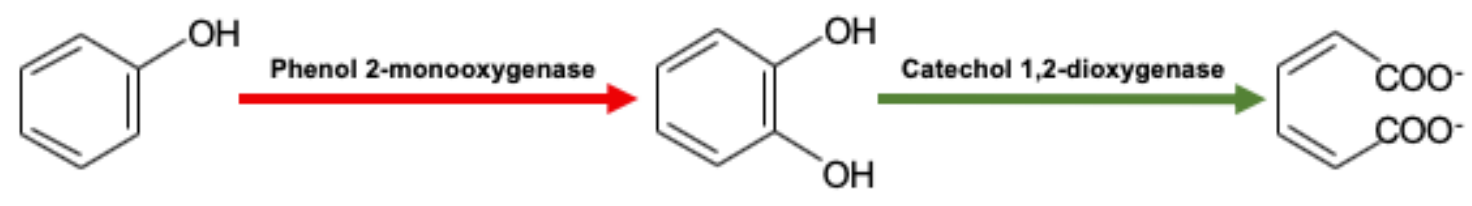

Phenol

Catechol

cis,cis-Muconate

\begin{tabular}{llllcc}
\hline Gene IDs & Product & EC number & \multicolumn{3}{c}{ Expression } \\
& & & 0.5 & 1.0 & 2.0 \\
\hline CTRG_00423 & Phenol 2-monooxygenase & 1.14 .13 .7 & NS & NS & -2.6 \\
CTRG_03102 & Phenol 2-monooxygenase & 1.14 .13 .7 & NS & NS & NS \\
CTRG_01732 & Catechol 1,2-dioxygenase & 1.13 .11 .1 & NS & NS & NS \\
CTRG_00171 & Catechol 1,2-dioxygenase & 1.13 .11 .1 & NS & NS & NS \\
\hline
\end{tabular}

\section{Figure 9}

The first and second step of the $\beta$-ketoadipate pathway in the biodegradation of phenol. Expression levels of genes involved in the first and second step of the $\beta$-ketoadipate pathway are represented by the values of log2(fold change) in response to different concentrations of phenol, compared with the control group. $\mathrm{NA}=$ not significant. 

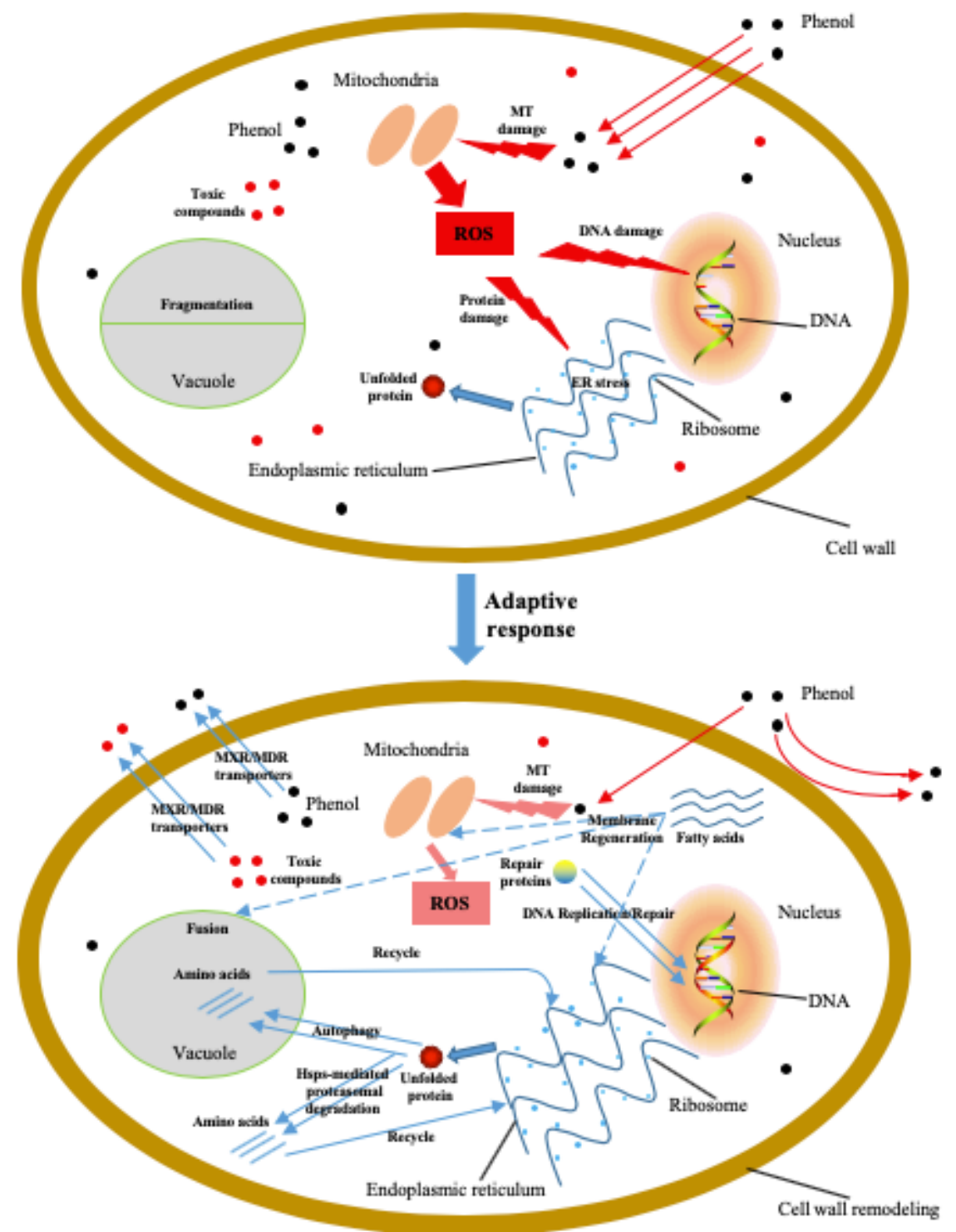

Figure 10

Schematic diagram showing cellular damage to $\mathrm{C}$. tropicalis SHC-03 caused by phenol, and tolerance mechanisms to phenol at the early stage of treatment. MT, mitochondria. 